\begin{tabular}{|c|c|}
\hline $\begin{array}{l}\text { 2. To: (Receiving Organization) } \\
\text { TWRS Materials \& Corrosion }\end{array}$ & $\begin{array}{l}\text { 3. From: (originating Organization) } \\
\text { TWRS Materials \& Corrosion }\end{array}$ \\
\hline $\begin{array}{l}\text { 5. Proj./Prog./Dept./0iv.: } \\
\text { TWRS }\end{array}$ & $\begin{array}{l}\text { 6. Design Authority/ Design Agent/Cog. } \\
\text { Engr.: } \\
\text { T. J. Bowman }\end{array}$ \\
\hline
\end{tabular}

8. Originator Remarks:

Compilation of CY 1995 Cathodic Protection Surveys performed for the 200 areas (East Tank Farms, West Tank Farms, Evaporator, PFP, Purex, 222-S).
11. Receiver Remarks:
11A. Design Baseline Document?
[] Yes
$[x]$ No

4. Related EDT No.:
N/A
$\begin{gathered}\text { 7. Purchase Order No.: } \\ \text { N/A }\end{gathered}$
9. Equip./Component No.:
N/A
10. System/B ldg./Facil ity:
200E/200W
12. Major Assm. Dwg. No.:
N/A
13. Permit/Permit Application No.:
N/A
14. Requi red Response Date:
$9 / 30 / 96$

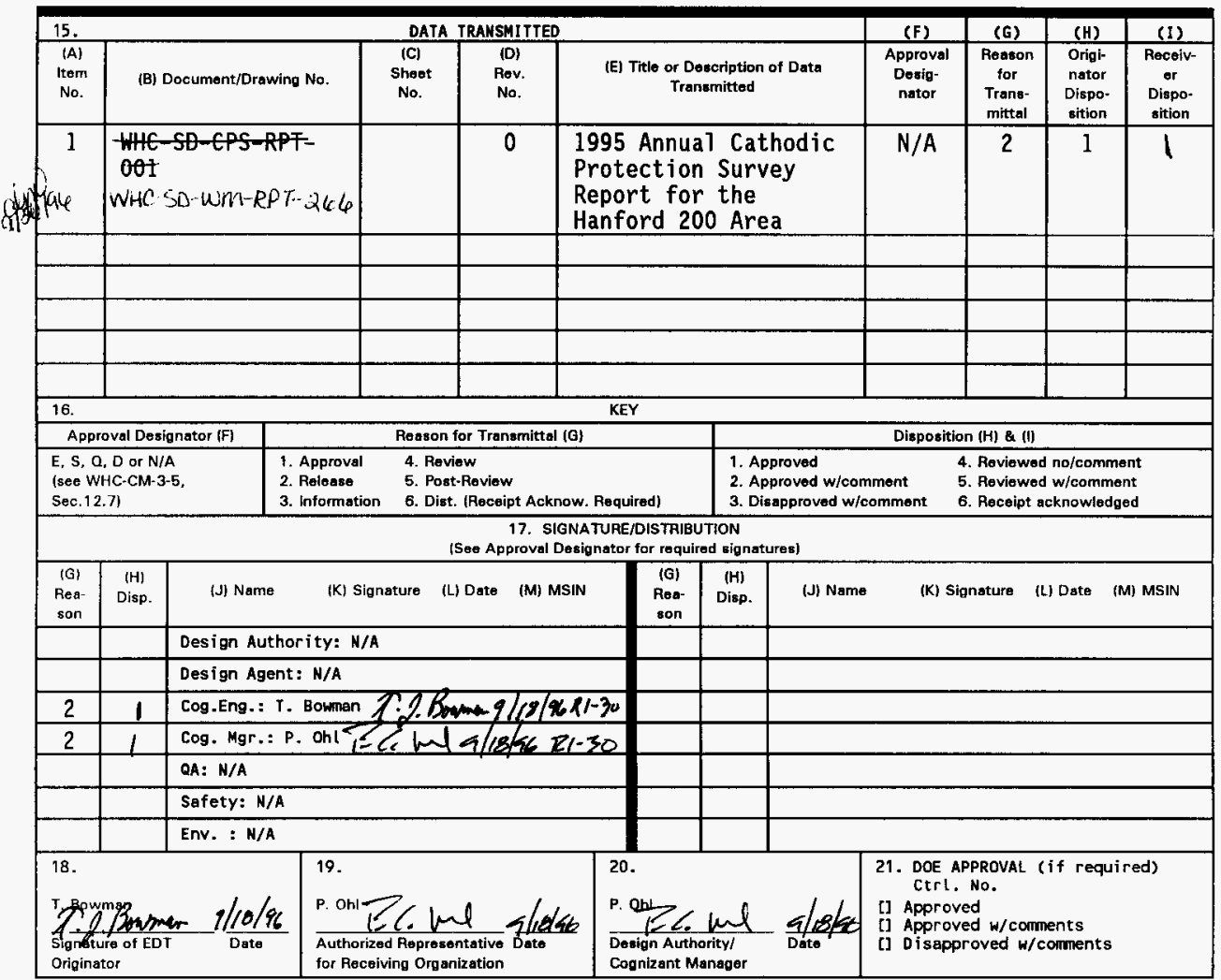




\section{Annual Cathodic Protection Survey Report for the Hanford 200 Area}

T. J. Bowman and P. C. Oh1

Westinghouse Hanford Company, Richland, WA 99352

U.S. Department of Energy Contract DE-AC06-87RL10930

$\begin{array}{lll}\text { EDT/ECN: } & 615262 & \text { UC: N/A } \\ \text { Org Code: } & 74 A 40 & \text { Charge Code: E52623 } \\ \text { B\&R Code: } & \text { EW3130010 } & \text { Total Pages: } 52 \text { so ens } \$ 2 \$ / 96\end{array}$

Key Words: corrosion, cathodic protection, transfer line

Abstract: Compilation of the CY 1995 Cathodic Protection Surveys performed for the 200 areas (East Tank Farms, West Tank Farms, Evaporator, PFP, Purex, 222-S Labs)

TRADEMARK DISCLAIMER. Reference herein to any specific comercial product, process, or service by trade name, trademark, manufacturer, or otherwise, does not necessarily constitute or imply its endorsement, recommendation, or favoring by the United States Government or any agency thereof or $i$ ts contractors or subcontractors.

Printed in the United States of America. To obtain copies of this document, contact: WHC/BCS Document Control Services, P.O. Box 1970, Mailstop H6-08, Richland WA 99352, Phone (509) 372-2420; Fax (509) 376-4989.

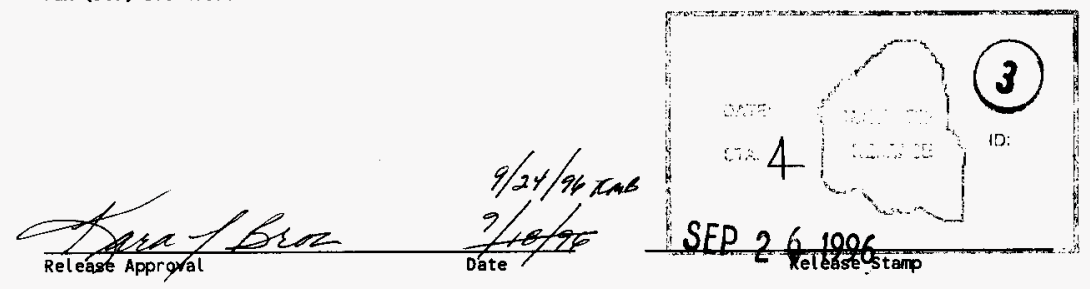

Approved for Public Release 
WHC-SD-WM-RPT-266, REV. 0

1995 ANNUAL CATHODIC PROTECTION SURVEY REPORT

FOR THE HANFORD 200 AREA

TABLE OF CONTENTS

Page

1.0 INTRODUCTION 1

1.1 Principals of Cathodic Protection 1

1.2 Cathodic Protection at Hanford 2

1.3 Washington State Cathodic Protection Requirements 8

1.4 Cathodic Protection Survey Procedure 8

2.01995 ANNUAL CATHODIC PROTECTION SURVEY RESULTS 10

2.1200 East Tank Farms 11

2.2 242-A Evaporator 11

2.3 PUREX Facility 20

2.4200 West Tank Farms 24

2.5 PFP Facilities 36

2.6 222-S Laboratory 40

3.0 ON-GOING DEVELOPMENT WORK AND TESTING REQUIREMENTS 46

$\begin{array}{lll}4.0 & \text { REFERENCES } & 47\end{array}$ 
WHC-SD-WM-RPT-266, REV. 0

1995 ANNUAL CATHODIC PROTECTION SURVEY REPORT FOR THE HANFORD 200 AREA

Page

Table 1: 200 Area Cathodic Protection Systems 5

Table 2: Pipe-to-Soil Potentials (VDC), AP Tank Farm 13

Table 3: Pipe-to-Soil Potentials (VDC), AW Tank Farm 17

Table 4: Pipe-to-Soil Potentials (VDC), PUREX 21

Table 5: West Tank Farm Cathodic Protection Subsystems 25

Table 6: West Tank Farm Rectifier Output (volt/amp) 26

Table 7: Pipe-to-Soil Potentials, "Off" (VDC), West Tank Farm 27

Table 8: Pipe-to-Soil Potentials (VDC), PFP 39

Table 9: Pipe-to-Soil Potentials (VDC), 222-S at Tap Setting B-5 43

Table 10: Pipe-to-Soil Potentials (VDC), 222-S at Tap Setting B-3 43

Table 11: Pipe-to-Soil Potentials (VDC), 222-S at Tap Setting A-2 44

Table 12: Pipe-to-Soil Potentials (VDC), 222-S at Tap Setting A-4 45 
WHC-SD-WM-RPT-266, REV. 0

1995 ANNUAL CATHODIC PROTECTION SURVEY REPORT FOR THE HANFORD 200 AREA

\subsection{INTRODUCTION}

Cathodic protection (CP), as a measure of providing corrosion protection to buried piping, has existed at Hanford since the $1940^{\prime} \mathrm{s}$. In 1980, the original $C P$ systems were evaluated and found out-dated, not operating properly, and in some cases, not operating at all. The CP systems were shut down and replaced with an updated design. The replacement systems were installed beginning in 1985 in a piece-meal fashion. Installation of new CP systems continue today, with most designs protecting new or upgraded transfer lines.

Since installation, the new $C P$ systems had received little attention until 1994 when all systems were assigned a single point of contact. In early 1995, cognizant ownership of these systems was assigned to Tank Waste Remediation System (TWRS) Materials and Corrosion Engineering (M\&CE). In addition, other $C P$ systems existing at the PUREX, PFP and 222-S Laboratory facilities are being supported by TWRS M\&CE. This allows all individual systems to be monitored as a complete system. Besides economic benefit, single ownership is beneficial as systems in proximity may impact each other by the formation of stray currents. One responsible individual can best organize the systematic testing.

This report is the first 'Annual Cathodic Protection Survey Report for the

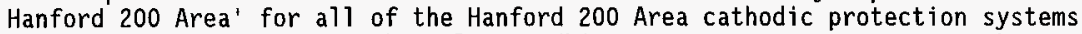
except those associated with B-Plant. This report encompasses test work collected in 1994, 1995, and up to midway of 1996.

\subsection{Principals of Cathodic Protection}

A11 buried transfer 1 ines at Hanford experience environments which may be detrimental to the lines due to soil corrosion. Corrosion is an electrochemical reaction of a metal structure exposed to an electrolyte, similar to an operating battery. Metal dissolves at the anode metal surface with electrons flowing to the cathode through the metal itself. Ionic current flows through the electrolyte.

There are several methods of protecting buried structures, such as material selection and application of coatings. One widely accepted method of corrosion protection in industry and at Hanford is the application of cathodic protection. Cathodic protection is the use of direct current electricity from an external source to mitigate corrosion by opposing the discharge of corrosion current. When cathodic protection is installed for maximum 
WHC-SD-WM-RPT-266, REV. 0

corrosion protection, all portions of the protected structure collect current from the surrounding environment and the entire exposed surface becomes

"cathodic."

\subsection{Cathodic Protection at Hanford}

The processing and waste storage facilities at the Hanford site are interconnected through a vast underground transfer system network. The transfer systems are primarily constructed of carbon steel and stainless steel. The soil burden covering the transfer systems provide the necessary radiation protection (shielding). The moist soil is corrosive to the steel transfer systems, with leaks being reported in the past. Corrosion protection of the piping is necessary to assure cont inued leak tightness. Furthermore, hazardous waste lines are required per Washington Administrative Code (WAC) to be protected from corrosion.

Cathodic protection of transfer lines at Hanford has existed since the late $1940^{\prime} \mathrm{s}$. The initial installations were to protect direct-buried stainless steel lines. These lines were reportedly failing from severe pitting corrosion (Jaske, 1954). The original CP systems were evaluated in 1980 by Battelle Columbus Laboratories (Payer, 1980). The study recommended that the operation of the $\mathrm{CP}$ systems be discontinued due to their age, condition, and very limited capabilities of evaluating operation. A replacement cathodic protection system was designed utilizing current technologies. Test stations were incorporated for evaluating the system operations to assure corrosion protection was being provided. Cathodic protection is only capable of protecting the outer surfaces of the transfer lines and not the inner walls from process side corrosion.

Eighteen tank farms exist at Hanford. Cathodic protection is applied to the transfer systems in ten of the tank farms. All of the double shell tank farms have cathodic protection. Selected single shell tank farms have cathodic protection. $C P$ is operating on the transfer lines that run between the tank farms and five operating facilities. $C P$ is operating on the transfer lines that run between one tank farm and another tank farm. Between July, 1994 and May, 1996, there were 33 individual rectifiers protecting the transfer systems and over 500 test stations were available for monitoring the CP systems' performances. Each test station is capable of supporting up to eight individual buried 1 ines.

Beginning in the mid-1980's, the existing CP systems were installed at Hanford under several major projects over a series of years. New CP systems are being installed during 1996. The complete $C P$ system has been installed with the 
intent of individual systems operating independently. A11 systems and related components, with the exception of the permanent reference electrodes, were designed with a minimum 20-year life expectancy.

Each $C P$ system has a current source consisting of a silicon diode rectifier. All rectifiers at Hanford, at year ending 1995, were manufactured by Good-All Electric, Incorporated of Fort Collins, Colorado. The enclosed oil-immersed design provides protection from dust and sand. Most rectifiers are supplied by 3 -phase 480 volt $A C$ current. Several 120 and 220 volt input rectifiers exist at Hanford. Each unit is manually adjusted by changing the transformer taps that are located on a panel above the $0 i 1$ reservoir. The purpose of the rectifier is to step down the local $A C$ power and convert it to a lower voltage DC output.

The anodes are the earth contacting electrodes through which the DC current is transmitted. The DC current that flows through the earth is picked up by the underground structures. The rectifier negative return cable(s) that are attached to the buried structures close the electronic/ionic circuit loop.

Typically, eight-inch diameter silicon cast iron anodes, mostly 96 inches long, are employed. Newer system designs are installing 48 inch long anodes. The anodes are prepackaged in a coke breeze backfilled canister. The anode canisters are 30 gauge galvanized stove pipe. Operation of the CP system will corrode away the stove pipe and allow the coke to provide the electrical contact with the soil.

The CP design at Hanford is of a distributed anode bed system. Anodes are installed either vertically or horizontally along the piping. The anodes installed over the waste tanks are horizontal. Anodes installed vertically provide protection to the piping around the entire circumference. The anodes are connected to a header cable. The cable is looped back to the rectifier for redundancy in the event the cable is severed. The anode header cable contains junction boxes at various locations. Cable branching allows some flexibility to adjust current flow. In some cases, anodes can be disconnected from the circuit to improve current distribution, reduce over-protection, or eliminate stray currents. The NEMA 4 anode junction boxes and anode distribution boxes incorporated in the system design contain eight electrically isolated terminal studs. Ten bus bars have been provided with each junction box assembly. The bus bars are used to interconnect the anode header and loop cables terminated on the studs. Surplus bus bars, if any, have been left in the bottom of each box for possible future use.

Test stations are installed at various locations along the transfer systems and are also installed adjacent to the waste storage tanks. The primary purpose of the test stations is to provide a means to measure structure-tosoil potentials. Each test station consists of a pair of wires (one \#12 AWG and one \#6 AWG). The wires are connected to the separate pipes that are designated to be monitored. The pair of wires are brought to the surface and 
WHC-SD-WM-RPT-266, REV. 0

terminated in a test box. Each test box is located in a buried enclosure with the top of the enclosure slightly above grade. Each lead is marked by a plastic tag identifying the pipe to which it is attached. Permanent reference electrodes are installed along the piping systems and these electrodes may be used when taking pipe-to-soil potential measurements. Test leads from the permanent reference electrodes, also identified with tags, are routed to the test stations.

Test leads are also attached on piping that is not intended to be protected. The purpose of these leads is to evaluate for stray currents. If a nonprotected structure picks up stray currents, accelerated corrosion will occur at the point where the current is discharged. If stray currents are located, the piping can easily be bonded within the test box. A test lead from the piping that is picking up stray current will be connected to one of the test leads that is attached to a protected pipe. This will mitigate the accelerated corrosion by providing a metallic current path back to the rectifier.

Stray currents migrating underground may be detrimental to isolated metallic structures. These currents can develop from the operating CP systems or from other grounded electrical sources. Where an electrically discontinuous

foreign structure in a voltage gradient becomes a conductor of DC current, the current is picked up by the foreign structure near the anodes or other high voltage source and discharges near the cathode or other low voltage area. The damage becomes evident in the form of accelerated corrosion which occurs where the stray current discharges from the foreign structure. The accelerated corrosion rate will reduce the useful life of the structure.

Stray current effects can be mitigated by incorporating the foreign structure into the CP system. This is easily achieved by providing direct bonds, resistor bonds, or diode bonds. These bonds allow the current to drain from the isolated structures. Sacrificial anodes can also be used in some situations as a current drain source when a mechanical bond is not wanted or feasible.

One method not recommended to reduce the probability of stray currents from the $C P$ system involves abandoning existing anodes near the foreign structure. This will prevent the creation of voltage gradients but will reduce the current flow to the piping that was intended to be protected. 
Color coding of the test leads in each test box generally exist. In most cases, the color coding is as described below:

\begin{tabular}{|c|c|}
\hline Test Lead & Installed Location \\
\hline $\begin{array}{l}\# 12 \text { red } \\
\# 6 \text { white }\end{array}$ & $\begin{array}{l}\text { Piping designated to receive } C P \\
\text { Piping designated to receive } C P\end{array}$ \\
\hline $\begin{aligned} & \# 12 \text { B1ue } \\
& \# 6 \text { Blue }\end{aligned}$ & $\begin{array}{l}\text { Piping not designated to receive } C P \\
\text { Piping not designated to receive } C P\end{array}$ \\
\hline $\begin{array}{rr}\# 12 & \text { Green } \\
\# 8 & \text { Black }\end{array}$ & $\begin{array}{l}\text { Permanent reference electrode } \\
\text { Permanent reference electrode }\end{array}$ \\
\hline
\end{tabular}

Test stations are also installed adjacent to waste storage tanks. Two deep reference electrode lead wires terminate in the test boxes. The deep permanent reference electrodes installed adjacent to the waste storage tanks allow monitoring of tank potentials. One reference electrode is installed at a depth of 10 feet and the other at 25 feet. Wires would have to be manually attached to the tank structure at these test locations for the purpose of measuring the electrical potentials on the tanks.

The voltage data collected at the test stations provide the information necessary to assure that the buried structures are being adequately protected.

Table 1 identifies the 200 area cathodic protection systems that were operating in 1995 and early 1996.

\begin{tabular}{|c|c|c|c|c|}
\hline Rectifier & Location & $\begin{array}{c}\text { Lines } \\
\text { Protected } \\
\end{array}$ & $\begin{array}{c}\text { Date } \\
\text { Installed } \\
\end{array}$ & $\begin{array}{c}\text { Associated } \\
\text { Area(s) }\end{array}$ \\
\hline 2 & $200 E$ & v021/022/023/714 & 1985 & $\begin{array}{l}\text { 202-A Bldg. } \\
\text { to AW farm }\end{array}$ \\
\hline 7 & $200 E$ & $\begin{array}{l}\text { V714/713, PW-4509, } \\
\text { SL-500, SN-600 } \\
\text { S609/D603/4607, } \\
\text { PW-4507/4508 } \\
\text { PW-4526/4550/4608 }\end{array}$ & $\begin{array}{l}1985 / \\
1991\end{array}$ & 241-AY Farm \\
\hline 8 & $200 E$ & 702A Vent Header & 1987 & 241-Ar Farm \\
\hline 9 & $200 E$ & $\begin{array}{l}\text { SL- } 100 / 101 / 500, \\
\text { SN-247/600, DR-314/326, } \\
\text { DR-327 }\end{array}$ & 1991 & 241-AX Farm \\
\hline
\end{tabular}


WHC-SD-WM-RPT-266, REV . 0

\begin{tabular}{|c|c|c|c|c|}
\hline Rectifier & Location & $\begin{array}{c}\text { Lines } \\
\text { Protected } \\
\end{array}$ & $\begin{array}{c}\text { Date } \\
\text { Installed } \\
\end{array}$ & $\begin{array}{c}\text { Associated } \\
\text { Area(s) } \\
\end{array}$ \\
\hline 10 & 200E & SN-247, CNDS-02/92 & 1991 & $\begin{array}{l}241-\mathrm{A}-401 \\
\text { Condenser and } \\
241-\mathrm{AX} \mathrm{Farm}\end{array}$ \\
\hline 11 & $200 E$ & $\begin{array}{l}\text { PSH-S608/S609/D603 } \\
/ 4607, P H-4507 / 4508 \\
\text { SL-160/500, SN-600 }\end{array}$ & $\begin{array}{l}1985 / \\
1991\end{array}$ & $\begin{array}{l}\text { 241-AN to } 241-\mathrm{AZ} \\
\text { Farms }\end{array}$ \\
\hline 12 & $200 \mathrm{E}$ & SN-247, CNDS-02/92 & 1991 & 241-A Complex \\
\hline 13 & $200 E$ & $\begin{array}{l}\text { SL-160/161/162 } \\
\text { SL-164/165/166 } \\
\text { SL-167/168, SN-247 } \\
\text { SN-260/261/263, } \\
\text { SN-264/265/266 } \\
\text { SN-267, CNOS-02/92 }\end{array}$ & 1991 & 241-AN Farm \\
\hline 14 & $200 E$ & $\begin{array}{l}\text { V714, SN-215/216 } \\
\text { SL-100/101, DR } 314\end{array}$ & $\begin{array}{c}1985 / \\
1991\end{array}$ & $\begin{array}{l}241-\mathrm{A} \text { to } 241-\mathrm{AY} \\
\text { Farm }\end{array}$ \\
\hline 15 & $200 E$ & SL-100/101，DR 314 & 1991 & 241-A Farm \\
\hline 16 & $200 E$ & $\begin{array}{l}\text { V714, SN-215/216, } \\
4001,4004,702, \\
\text { PAW/NHW 4006/4018, } \\
\text { PAW/NHW 4002/814/4015 }\end{array}$ & 1985 & $\begin{array}{l}241-A W \\
\text { Farm, 204-AR }\end{array}$ \\
\hline 17 & $200 \mathrm{E}$ & $\mathrm{SN}-215 / 216$ & 1985 & $\begin{array}{l}\text { 244-AR Tank } \\
\text { Vault }\end{array}$ \\
\hline 18 & $200 E$ & $\begin{array}{l}\text { SL-113/167/168, } \\
\text { SN-215/216/219; } \\
\text { SN-220/259/270, } \\
\text { DR-334/335/343; } \\
702,4001,4004\end{array}$ & 1985 & $\begin{array}{l}242-A \\
\text { Building }\end{array}$ \\
\hline 19 & $200 \mathrm{E}$ & $\begin{array}{l}\text { SL-161/162/163 } \\
\text { SL-164/165/166 } \\
\text { SL-167/168/169 } \\
\text { SN-261/262/263 } \\
\text { SN-264/265/269 } \\
\text { SN-270/271/219 } \\
\text { SN-220/266/267 } \\
\text { SN-268/272/610, } \\
\text { DR-334/335/343 }\end{array}$ & 1985 & $\begin{array}{l}\text { 241-AH } \\
\text { Farm }\end{array}$ \\
\hline 22 & $200 \mathrm{w}$ & 202,203 & 1992 & $\begin{array}{l}241-z \text { to } \\
241-1 X \text { Farms }\end{array}$ \\
\hline 23 & $200 \mathrm{w}$ & 202,203 & 1993 & $\begin{array}{l}241-2 \text { to } \\
241-7 x \text { farms }\end{array}$ \\
\hline
\end{tabular}


WHC-SD-WM-RPT-266, REV. 0

\begin{tabular}{|c|c|c|c|c|}
\hline Rectifier & Location & $\begin{array}{c}\text { Lines } \\
\text { Protected }\end{array}$ & $\begin{array}{c}\text { Date } \\
\text { Installed }\end{array}$ & $\begin{array}{l}\text { Associated } \\
\text { Area(s) }\end{array}$ \\
\hline 24 & $200 \mathrm{w}$ & Drain Line & 1993 & $\begin{array}{l}251-U-151 / 152 / 153 \\
\text { Diversion Box to } \\
241-U-301 \\
\text { Catch Tank }\end{array}$ \\
\hline 25 & $200 \mathrm{w}$ & $\begin{array}{l}\text { SL- } 101, \quad S N-216, \\
\text { SN-282, OR-327 }\end{array}$ & 1993 & $\begin{array}{l}\text { Between } 241-U \text { and } \\
241-\mathrm{SX} / \mathrm{SY} \text { Farms }\end{array}$ \\
\hline 26 & $200 \mathrm{w}$ & $S N-283 / 284$ & 1993 & $\begin{array}{l}\text { 242-S Evaporator } \\
\text { to 02E Pump Pit } \\
\text { above } \\
241-\mathrm{SY}-102\end{array}$ \\
\hline 27 & $200 \mathrm{w}$ & $V-560 / 561 / 562$ & 1993 & $\begin{array}{l}\text { 241-SY Farm to } \\
244-\mathrm{S} \text { Receiver } \\
\text { and } 241-\mathrm{S}-151 \\
\text { Diversion Box }\end{array}$ \\
\hline 31 & $200 E$ & $\begin{array}{l}\text { SL-100/101/502 } \\
\text { SL-504/505, } \\
\text { PW-4523/4526/4531, } \\
\text { DR- } 314 / 327 / 370 \text { and } \\
\text { Annul us Vent Pipes Around } \\
241-\text { AY-101, and 241-AY- } \\
102\end{array}$ & 1991 & $\begin{array}{l}\text { 241-AY Farm to } \\
\text { 241-AX A\&B Vaults }\end{array}$ \\
\hline 33 & $200 E$ & $\begin{array}{l}\text { GR-200, -202, }-203 \\
\text { EW-200, -202, }-203\end{array}$ & $\begin{array}{c}1991 \text {, } \\
\text { turned off in } \\
1996\end{array}$ & Grout \\
\hline 34 & $200 \mathrm{w}$ & $\begin{array}{l}V-387 / 398 / 404, \\
D R-820\end{array}$ & 1993 & $\begin{array}{l}\text { Process Lines } \\
\text { near } \\
244-T X-152 \\
\text { Diversion BoX }\end{array}$ \\
\hline 35 & $200 \mathrm{w}$ & $\begin{array}{l}\text { SN-216/282, } \\
\text { SL-101, DR-327, drain } \\
\text { line }\end{array}$ & 1993 & 241-U Farm \\
\hline 36 & $200 \mathrm{w}$ & $\begin{array}{l}\text { SL- } 175 / 177 / 178 \\
\text { SL-179/180, } \\
\text { SN-277/278/279 } \\
\text { SN-280/282/283 } \\
\text { SN-284/285/286 V561, } \\
\text { V562, OR 327 }\end{array}$ & 1996 & 241-SY Farm \\
\hline 37 & $200 \mathrm{w}$ & 202,203 & 1993 & $\begin{array}{l}\text { Saltwell receiver } \\
\text { in 241-TX Farm }\end{array}$ \\
\hline 40 & 200E & $\begin{array}{ll}G R-300, & -304,-305 \\
E W-300,-304, & -305\end{array}$ & $\begin{array}{l}1991 \text {, } \\
\text { turned off in } \\
1996\end{array}$ & Grout \\
\hline 44 & $200 \mathrm{w}$ & $\begin{array}{l}\text { Laboratory upgrade } \\
\text { ducting, } D R-1,-2\end{array}$ & 1995 & $222-s$ \\
\hline
\end{tabular}


WHC-SD-WM-RPT-266, REV. 0

\begin{tabular}{|c|c|c|c|c|}
\hline Rectifier & Location & $\begin{array}{l}\text { Lines } \\
\text { Protected }\end{array}$ & $\begin{array}{c}\text { Date } \\
\text { Installed }\end{array}$ & $\begin{array}{c}\text { Associated } \\
\text { Area(s) }\end{array}$ \\
\hline 45 & $200 \mathrm{~W}$ & LSW, HSW and Spares & 1994 & PFP \\
\hline R1 & $200 E$ & $\begin{array}{l}\text { SL- } \\
510 / 509 / 610 / 609 / 515 / 517 \\
\text { SN-615/617 }\end{array}$ & 1985 & 241-AP \\
\hline$R 2$ & 200E & $\begin{array}{l}\text { SL-518/516 } \\
\text { SN-618/616 } \\
\end{array}$ & 1985 & $241-A P$ \\
\hline RB220 & $200 E$ & v720 & 1987 & $\begin{array}{l}\text { 244-AR, } \\
\text { AY Farm }\end{array}$ \\
\hline EN-RECT -5745 & $200 \mathrm{~W}$ & WT $-5701 / 5702 / 5703 / 5704$ & 1996 & $222-5$ \\
\hline
\end{tabular}

\subsection{Washington State Cathodic Protection Requirements}

The Hanford hazardous waste storage facilities are currently operating under an interim status permit from the Washington Department of Ecology. Eventually the Hanford site will be issued a final status permit. At this time the Hanford site will begin operating as a permitted Dangerous Waste Storage Facility. The Washington Administrative Codes will likely apply to the hazardous waste storage facilities. WAC 173-303-640 requires corrosion protection of the waste storage and transfer system.

Impressed current CP existing on Hanford's underground transfer systems mitigates corrosion. Periodic assessment of the $C P$ system operation is required and necessary to assure the systems are operating and to assure that adequate corrosion protection is applied to the buried structures. Bimonthly rectifier checks and annual CP surveys are mandated by the State of Washington per WAC 173$303-640$.

\subsection{Cathodic Protection Survey Procedure}

The primary objective of performing $C P$ surveys is to ensure that adequate corrosion protection is provided on the designated piping. Cathodic protection surveys were performed per Tank Farm Maintenance Procedure 6-TF-357, Testing of Cathodic Protection System. The rectifiers were visually examined for physical damage, rectifier oil cleanliness, and oil level. All panel meters were checked 
for calibration as compared to a calibrated portable multimeter. All voltage readings were taken across the anode $(+)$ and cathode $(-)$ terminals. The output current was determined by reading the voltage drop in millivolts across the calibrated shunt and converting to amperes using $0 \mathrm{hm}^{\prime} \mathrm{s}$ Law $(V=I R)$.

Pulse generators were installed in series with all nearby rectifier units prior to pipe-to-soil potential measurements. The pulse generators provide a synchronized interruption of all nearby anode currents. Current flowing during the test will affect the measured voltage by adding an extraneous voltage to the pipe-to-soil potential values. The interrupted currents generated by the rectifier-pulse generator series circuit create pipe-to-soil potentials on the piping with no extraneous soil voltage drop to measure. The soil voltage drop is caused by the flow of $D C$ current flow through the soil. The current free potential measurement is called the polarized pipe-to-soil potential.

Continuity tests were performed to identify those structures and test leads not continuous with the system. These tests were performed by measuring the resistance between both test leads from each pipe and measuring the resistance between the different pipes.

Potential readings were measured at selected test stations on selected structures. These structures were identified before the testing and after a review of previous $C P$ survey data and system drawings. All potential readings were measured with a high impedance waveform analyzer relative to a portable copper/copper sulfate reference electrode. Selected permanent copper/copper sulfate reference electrodes were also utilized. The waveform analyzer was used to measure the resulting IR error free structure-to-soil potentials. The wave form analyzer detects the pulse-generated interruptions and processes the "ON" and "OFF" (IR error free) potentials.

The operating criteria to which the cathodic protection systems are evaluated is the NACE recommended practice RP0285-95, "Corrosion Control of Underground Storage Tank Systems by Cathodic Protection". Two of the acceptance criteria specified in NACE RP0285-95 are used as standards at Hanford. The widely accepted criterion of a polarized pipe-to-soil potential of -0.85 volt DC, relative to a copper/copper sulfate reference electrode, on buried steel structures is considered the most conservative standard in use at Hanford. The potential measured during the "OFF" cycle generated by the pulse generatorrectifier series arrangement represents the IR-error free (polarized) structureto-soil potential.

A second criterion to which cathodic protection is considered protective is described in RP0285-95 as the $100 \mathrm{mV}$ potential shift. A structure is considered protected from corrosion if a measurable potential shift of $100 \mathrm{mV}$ or more in the negative direction occurs upon system energization. For practical application at Hanford, this occurs when the instant "OFF" potential is at least $100 \mathrm{mV}$ more negative than the "NATIVE" potential. 
The complex configuration of the tank farms transfer systems with different material types, different construction designs, and proximity to large structures, such as waste tanks or valve pits, creates different current requirements and polarization rates. The NACE criteria, which serves as a guide for evaluating the operation of CP systems, is not universal for all structures and environments. These criterion are more directed at ideal hypothetical conditions of a single metal exposed to a uniform homogeneous environment, which does not exist at Hanford. The most conservative approach presented in NACE Recommended Practice RP0285-95 is to utilize the most anodic metal and proceed to achieve a sufficient potential to polarize the cathode to the open circuit potential of the most anodic material. The supplied current assures a level of protection to the less anodic materials.

Since carbon steel is considered the most anodic material buried at Hanford, the -0.85 volt criteria approximates the protection requirement criteria to achieve total corrosion mitigation. The difficulty with this value is the complex configuration of the tank farms. Near the tanks that have reinforced concrete, the potential achieved will generally be less than at remote locations or even near different materials such as stainless steel structures. Considerable testing would be required to determine the actual protection criteria for the multitude of conditions and locations. Measured potentials near the large structures are usually found more positive (i.e., $-0.50 \mathrm{~V}$ ) than the -0.85 criteria. Arbitrarily increasing the rectifier outputs to make this potential more negative to meet the -0.85 volt criteria may cause more harm than good and possibly damage the tank components. Investigations are required to evaluate the more positive potentials near the tanks and other large structures and to determine the impacts of increasing the rectifier outputs. The 100 millivolts shift criteria is the established standard of judgement that is being used at Hanford when the -0.85 polarized potential is not being realized.

Earlier cathodic protection surveys identified several permanent copper/copper sulfate reference electrodes as being questionable references. A difference in potentials between the permanent and portable reference electrodes was noted in several cases. Only a very minute difference should exist between the two reference electrodes. This is due to the resistance of the separating soi1. The higher than anticipated potential difference may be due to aging of the permanent reference cells, or dry soil, or other physical conditions. Significant differences (greater than 0.1 VDC) indicate that data obtained with the permanent reference electrode is questionable.

\subsection{ANNUAL CATHODIC PROTECTION SURVEY RESULTS}

Results of the CP surveys performed during calendar year 1995 are presented in the following sections. The pipe-to-soil potential data is presented in tables 2 through 12. Structures that did not meet the standard $-0.85 \mathrm{~V}$ criterion have 
WHC-SD-WM-RPT-266, REV. 0

been undergoing evaluation for meeting the $-100 \mathrm{mV}$ potential shift criterion or have had the rectifiers adjusted. Since the whole system is still in the process of being optimized, no exceptions are explicitly called out in this report.

\subsection{East Tank Farms}

The standard cathodic protection surveys were not performed in the A-Tank Farm Complex due to the construction activities related to the $W-030$ and the $W-320$ projects. The resurvey of January, 1995 of the A complex was conducted at key test stations. Results of the 1995 resurvey are documented in 'Cathodic Protection System Resurvey' and this survey was accomplished by Corrpro Companies, Inc.

The construction activities de-energized many of the rectifiers in the A-Complex and AN Tank Farm. The excavation activities dislocated several test stations and anodes. The results of any survey performed during the construction activities would not encompass the influence of the separate CP systems upon each other. The standard complete survey is to be performed upon completion of the Projects. The Projects' $C P$ operational test procedures are to be performed in conjunction with the CP surveys.

\subsection{2-A Evaporator}

The Evaporator CP systems, specifically those associated with the AP tank farm (Rectifier RI and R2) and AW tank farm (Rectifier 19), were surveyed in association with the PUREX facility. The annual survey requires coordination with the PUREX facility and installation of test equipment on all nearby rectifiers. The nearby rectifier systems may affect each other by generating inadvertent stray currents on the piping where the potentials are measured at the test stations. The rectifiers possibly affecting each other are those in and nearby the AP and AW Tank Farms and the PUREX facility. The systems north of the Evaporator were not surveyed due to the aforementioned construction activities in the A-Tank Farm Complex. These systems will be surveyed as a complete system upon completion of the $W-030$ and $W-320$ projects.

The $C P$ systems provide corrosion protection to the underground transfer lines within the AP and AW tank farms. Besides these lines in the farms, other lines in the vicinity may be electrically connected to the system and may be picking up protective CP currents.

Pulse generators were installed on Tank Farm's Rectifiers 19, R1, and R2 and on PUREX's Rectifier 2. These rectifiers protect transfer lines in the AW-Tank farm area and the AP Tank Farms area and the PUREX facility area. These rectifiers, pulsing in synch, interrupt all nearby underground currents that may influence the measured potentials. The instant "OFF" (polarized) potentials provide an accurate assessment of the degree of corrosion protection provided to the buried 
transfer lines. A wave form analyzer (WFA) was used to measure the "ON"/ "OFF" potentials. The WFA captures both the high and low pipe-to-soil potentials representative of the on/off cycles of the pulse generators.

\section{SURVEY RESULTS AND DISCUSSION}

Each of the rectifiers is a standard oil-filled rectifier operating under constant DC voltage. The rectifiers were visualiy inspected and found in good condition. The rectifier oil appeared clean, in good condition, and at the proper leve1. No oil leaks from the rectifiers were found. During the wet spring of 1995 Rectifier 19 was continuously over-amping the fuse device. This was due to circuit overloads. The tap settings had been adjusted as high as possible. This was the recommendation of the baseline July 1994 survey. The taps were reduced from D-1 to $\mathrm{C}-2$ prior to surveying. Monitoring assured the rectifier remained operational. The operational characteristics of the rectifiers prior to performing the surveys are provided below:

\section{Rectifier 19}

Make: Good-Al1 Electric

Model: CSOYTF 40-12 ENTZ

Serial \#: $85 \mathrm{C} 2858$

Part \#: 0030537

Rectifier Input: 480 volts $(A C), 0.75$ amps

Maximum Rectifier Output: 40 volts (DC), 12 amps

Taps (as found): $\mathrm{C}-2$

Rectifier Output:

Current (as found):

Panel Readings

26 VDC

13 amps

Shunt: 100 amps 050 mVolts

\section{Rectifier Rl}

Make: Good-A11 Electric

Model: CSOYTD 100-60 EGNZ

Serial \#: 85C2388

Rectifier Input: 480 volts (AC), 8.6 amps

Maximum Rectifier Output: 100 volts (DC), 60 amps

Taps (as found): B-1

Rectifier output:

Current (as found):

Shunt: 80 amps 50 mVolts

\section{Panel Readings \\ 32 VDC \\ 24 amps}


WHC-SD-WM-RPT-266, REV. 0

Rectifier R2

Make: Good-A11 Electric

Model: CSOYTD 100-60 EGNZ

Serial \#: 85C2389

Rectifier Input: 480 volts $(A C), 8.6$ amps

Maximum Rectifier Output: 100 volts (DC), 60 amps

Taps (as found): D-2

Rectifier Output:

Current (as found):

Panel Readings

92 VDC

35 amps

Shunt: 80 amps 050 mVolts

The key test stations within the tank farms were selected for testing. These test stations were selected by analyzing previous data and by reviewing the configuration drawings. The pipe-to-soil potentials were measured with a portable reference ce11 rather than the permanent reference cells. The portable reference cell is considered more accurate than the older deteriorating permanent cells.

The results of the surveys in AP and AW Tank Farms are presented in Table 2 and Table 3 respectively. These results are compared to those measured during the basel ine CP survey (4/94-6/94) and compared to a re-survey that was performed in January of 1995 .

\begin{tabular}{|c|c|c|c|c|c|c|c|}
\hline \multirow{2}{*}{$\begin{array}{c}\text { Test } \\
\text { Station }\end{array}$} & \multirow{2}{*}{$\begin{array}{c}\text { Buried } \\
\text { Structure }\end{array}$} & \multicolumn{2}{|c|}{ July, 1994} & \multicolumn{2}{|c|}{ January, 1995} & \multicolumn{2}{|c|}{ August, 1995} \\
\hline & & ON & OFF & ON & OFF & ON & OfF \\
\hline $79-01$ & $R W$ & -1.524 & -1.012 & & & -1.787 & -1.130 \\
\hline $78-03$ & $\begin{array}{l}\text { SN-602 } \\
\text { SL }-509 \\
\text { SL }-510 \\
\text { SN-609 } \\
34 \quad \text { RW }\end{array}$ & $\begin{array}{l}-1.992 \\
-1.991 \\
-1.990 \\
-1.9991 \\
-1.992\end{array}$ & $\begin{array}{l}-1.176 \\
-1.1777 \\
-1.174 \\
-1.176 \\
-1.178 \\
\end{array}$ & & & $\begin{array}{l}-2.542 \\
-2.542\end{array}$ & $\begin{array}{l}-1.268 \\
-1.259\end{array}$ \\
\hline $93-01$ & $S N-650$ & -0.946 & -0.598 & & & -1.191 & -0.726 \\
\hline $80-07(A)$ & $\begin{array}{l}\text { PW } 812 \\
\text { RH-S } \\
\text { AE } \\
\text { INT } \\
\text { SL-512 } \\
\text { SN- } 612\end{array}$ & $\begin{array}{l}-0.458 \\
-0.454 \\
-0.552 \\
-0.452 \\
-0.469 \\
-0.469\end{array}$ & $\begin{array}{l}-0.400 \\
-0.400 \\
-0.399 \\
-0.400 \\
-0.402 \\
-0.399 \\
\end{array}$ & & & $\begin{array}{l}-0.699 \\
-0.656\end{array}$ & $\begin{array}{l}-0.551 \\
-0.553\end{array}$ \\
\hline $80-7(B)$ & $\begin{array}{c}R W-N \\
\text { SN-N22 } \\
\text { SN-621 }\end{array}$ & $\begin{array}{l}-0.453 \\
-0.459 \\
-0.447\end{array}$ & $\begin{array}{l}-0.400 \\
-0.0998 \\
-0.412\end{array}$ & & & $\begin{array}{l}-0.654 \\
-0.672\end{array}$ & $\begin{array}{l}-0.548 \\
-0.554\end{array}$ \\
\hline
\end{tabular}


WHC-SD-WM-RPT-266, REV. 0

\begin{tabular}{|c|c|c|c|c|c|c|c|}
\hline \multirow{2}{*}{$\begin{array}{c}\text { Test } \\
\text { Station }\end{array}$} & \multirow{2}{*}{$\begin{array}{c}\text { Buried } \\
\text { Structure }\end{array}$} & \multicolumn{2}{|c|}{ Jut $y, 1994$} & \multicolumn{2}{|c|}{ January, 1995} & \multicolumn{2}{|c|}{ August, 1995} \\
\hline & & ON & OFF & $\mathrm{ON}$ & OFF & ON & OFF \\
\hline $80-24$ & SN- 621 & -2.962 & -1.195 & & & -4.336 & -1.549 \\
\hline $80-23(A)$ & $\begin{array}{c}\text { RW-S } \\
\text { INT T23 } \\
\text { ANN EXH } \\
\text { RW-N } \\
\text { SN-614 } \\
\text { PW- } 814 \\
\end{array}$ & $\begin{array}{l}-0.501 \\
-0.501 \\
-0.500 \\
-0.500 \\
-0.501 \\
-0.500 \\
\end{array}$ & $\begin{array}{l}-0.386 \\
-0.387 \\
-0.387 \\
-0.387 \\
-0.387 \\
-0.386 \\
\end{array}$ & $\begin{array}{l}-0.868 \\
-0.868 \\
-0.867 \\
-0.868 \\
-0.869 \\
-0.869 \\
\end{array}$ & $\begin{array}{l}-0.548 \\
-0.548 \\
-0.547 \\
-0.552 \\
-0.552 \\
-0.545\end{array}$ & $\begin{array}{l}-0.890 \\
-0.891\end{array}$ & $\begin{array}{l}-0.635 \\
-0.637\end{array}$ \\
\hline $80-23(B)$ & SN-621 & -0.501 & -0.385 & -0.870 & -0.550 & -0.895 & -0.639 \\
\hline $81-18(A)$ & $\begin{array}{ll}\text { AE } & 104 \\
\text { AE } & 103 \\
\text { PE } & 104 \\
\text { PE } & 103 \\
\text { PE } & 102 \\
\text { PE } & 101 \\
\end{array}$ & $\begin{array}{l}-0.795 \\
-0.797 \\
-0.797 \\
-0.797 \\
-0.797 \\
-0.797 \\
\end{array}$ & $\begin{array}{l}-0.488 \\
-0.489 \\
-0.489 \\
-0.490 \\
-0.487 \\
-0.490 \\
\end{array}$ & & & $\begin{array}{l}-1.430 \\
-1.432\end{array}$ & $\begin{array}{l}-0.594 \\
-0.643\end{array}$ \\
\hline $81-18(B)$ & $\begin{array}{ll}\text { AE } 102 \\
\text { AE } 101 \\
\end{array}$ & $\begin{array}{l}-0.797 \\
-0.795 \\
\end{array}$ & $\begin{array}{l}-0.489 \\
-0.488 \\
\end{array}$ & & & $\begin{array}{l}-1.429 \\
-1.429 \\
\end{array}$ & $\begin{array}{l}-0.643 \\
-0.637 \\
\end{array}$ \\
\hline $81-19$ & $\begin{array}{c}\text { RW } \\
\text { PE } \\
\text { 6" EM } 26 \\
\text { 4" } \text { OVERFLW } \\
\end{array}$ & $\begin{array}{l}-0.888 \\
-0.889 \\
-0.889 \\
-0.888 \\
\end{array}$ & $\begin{array}{l}-0.761 \\
-0.759 \\
-0.758 \\
-0.758 \\
\end{array}$ & & & $\begin{array}{l}-1.267 \\
-1.265\end{array}$ & $\begin{array}{l}-0.956 \\
-0.949\end{array}$ \\
\hline $81-10(A)$ & $\begin{array}{ll}\text { AE } & 107 \\
\text { AE } & 106 \\
\text { AE } & 105 \\
\text { AE } & 108 \\
\text { PE } & 106 \\
\text { PE } & 105 \\
\end{array}$ & $\begin{array}{l}-0.729 \\
-0.729 \\
-0.728 \\
-0.729 \\
-0.729 \\
-0.729 \\
\end{array}$ & $\begin{array}{l}-0.519 \\
-0.519 \\
-0.519 \\
-0.516 \\
-0.516 \\
-0.516\end{array}$ & & & $\begin{array}{l}-1.214 \\
-1.214\end{array}$ & $\begin{array}{l}-0.735 \\
-0.738\end{array}$ \\
\hline $81-10(B)$ & $\begin{array}{ll}\text { PE } & 108 \\
\text { PE } & 107 \\
\end{array}$ & $\begin{array}{r}-0.729 \\
-0.729 \\
\end{array}$ & $\begin{array}{l}-0.515 \\
-0.515 \\
\end{array}$ & & & $\begin{array}{l}-1.214 \\
-1.214 \\
\end{array}$ & $\begin{array}{l}-0.738 \\
-0.735 \\
\end{array}$ \\
\hline $82-06(A)$ & $\begin{array}{c}\text { PW } 816 \\
\text { SN- } 616 \\
\text { SL-516 } \\
\text { RW-N } \\
\text { RW-S } \\
\text { INT } \\
\end{array}$ & $\begin{array}{l}-0.888 \\
-0.888 \\
-0.888 \\
-0.887 \\
-0.887 \\
-0.888 \\
\end{array}$ & $\begin{array}{l}-0.679 \\
-0.677 \\
-0.679 \\
-0.677 \\
-0.679 \\
-0.678 \\
\end{array}$ & $\begin{array}{l}-1.812 \\
-1.812 \\
-1.812 \\
-1.809 \\
-1.809 \\
-1.809 \\
\end{array}$ & $\begin{array}{l}-0.979 \\
-0.973 \\
-0.973 \\
-0.978 \\
-0.981 \\
-0.977 \\
\end{array}$ & $\begin{array}{l}-1.263 \\
-1.263\end{array}$ & $\begin{array}{l}-0.903 \\
-0.896\end{array}$ \\
\hline $82-06(B)$ & $\mathrm{AE}$ & -0.887 & -0.681 & -1.809 & -0.977 & -1.262 & -0.900 \\
\hline $82-07$ & $\begin{array}{c}\text { AE } 106 \\
\text { AE } 108 \\
\text { PE } 108 \\
\text { SL- } 518 \\
\text { SN- } 618 \\
\text { INT } \\
\text { EXHAUST }\end{array}$ & $\begin{array}{l}-1.501 \\
-1.505 \\
-1.504 \\
-1.507 \\
-1.506 \\
-1.505 \\
-0.713\end{array}$ & $\begin{array}{l}-1.048 \\
-1.049 \\
-1.048 \\
-1.045 \\
-1.049 \\
-1.047 \\
-0.381 \\
\end{array}$ & & & $\begin{array}{l}-2.005 \\
-2.005\end{array}$ & $\begin{array}{l}-1.179 \\
-1.179\end{array}$ \\
\hline $82-13(A)$ & $\begin{array}{c}\text { RW-N } \\
\text { SN-518 } \\
\text { RW-S } \\
\text { AE } \\
\text { INT } \\
\text { PW }\end{array}$ & $\begin{array}{l}-0.722 \\
-0.722 \\
-0.722 \\
-0.721 \\
-0.721 \\
-0.721\end{array}$ & $\begin{array}{l}-0.610 \\
-0.606 \\
-0.611 \\
-0.608 \\
-0.606 \\
-0.612 \\
\end{array}$ & & & $\begin{array}{l}-1.165 \\
-1.166\end{array}$ & $\begin{array}{l}-0.873 \\
-0.875\end{array}$ \\
\hline
\end{tabular}


WHC-SD-WM-RPT-266, REV. 0

\begin{tabular}{|c|c|c|c|c|c|c|c|}
\hline \multirow{2}{*}{$\begin{array}{c}\text { Test } \\
\text { Station }\end{array}$} & \multirow{2}{*}{$\begin{array}{c}\text { Buried } \\
\text { Structure }\end{array}$} & \multicolumn{2}{|c|}{ July, 1994} & \multicolumn{2}{|c|}{ January, 1995} & \multicolumn{2}{|c|}{ August, 1995} \\
\hline & & ON & OFF & ON & OFF & ON & OFF \\
\hline $82-13(B)$ & $S N-618$ & -0.722 & -0.612 & & & -1.162 & -0.879 \\
\hline $82-10$ & $\begin{array}{c}\text { SN-617 } \\
\text { SL-517 } \\
\text { AE } \\
\text { PE } \\
\text { INT }\end{array}$ & $\begin{array}{l}-1.690 \\
-1.691 \\
-1.690 \\
-1.690 \\
-1.689\end{array}$ & $\begin{array}{l}-0.938 \\
-0.936 \\
-0.933 \\
-0.934 \\
-0.936\end{array}$ & & & $\begin{array}{l}-2.783 \\
-2.784\end{array}$ & $\begin{array}{l}-1.188 \\
-1.183\end{array}$ \\
\hline $82-03$ & $\begin{array}{l}V \text { M22 } \\
\text { PW } 825\end{array}$ & $\begin{array}{l}-1.437 \\
-1.438 \\
\end{array}$ & $\begin{array}{l}-0.690 \\
-0.688\end{array}$ & & & $\begin{array}{l}-1.989 \\
-1.992\end{array}$ & $\begin{array}{l}-0.820 \\
-0.825\end{array}$ \\
\hline $82-01(A)$ & $\begin{array}{l}\text { PW } 825 \\
\text { RW N } \\
\text { INT } \\
\text { PW } 815 \\
\text { RW S } \\
\text { AE }\end{array}$ & $\begin{array}{l}-0.580 \\
-0.579 \\
-0.579 \\
-0.579 \\
-0.578 \\
-0.579\end{array}$ & $\begin{array}{l}-0.417 \\
-0.413 \\
-0.412 \\
-0.411 \\
-0.413 \\
-0.412\end{array}$ & & & $\begin{array}{l}-0.709 \\
-0.708\end{array}$ & $\begin{array}{l}-0.494 \\
-0.495\end{array}$ \\
\hline $82-01(B)$ & $\begin{array}{l}\text { SN- } 615 \\
\text { SL-515 }\end{array}$ & $\begin{array}{l}-0.580 \\
-0.580\end{array}$ & $\begin{array}{l}-0.417 \\
-0.415\end{array}$ & & & $\begin{array}{l}-0.710 \\
-0.711\end{array}$ & $\begin{array}{l}-0.498 \\
-0.500\end{array}$ \\
\hline $82-02(A)$ & $\begin{array}{c}\text { SN-617 } \\
\text { INT } \\
2^{11} \text { RW } \\
\text { SN- } 615 \\
\text { SL-517 } \\
\text { SL-515 } \\
\end{array}$ & $\begin{array}{l}-1.617 \\
-1.615 \\
-1.626 \\
-1.617 \\
-1.618 \\
-1.617 \\
\end{array}$ & $\begin{array}{l}-1.134 \\
-1.134 \\
-1.132 \\
-1.132 \\
-1.132 \\
-1.129 \\
\end{array}$ & & & $\begin{array}{l}-1.937 \\
-1.937\end{array}$ & $\begin{array}{l}-1.124 \\
-1.126\end{array}$ \\
\hline $82-02(B)$ & $\begin{array}{ll}\text { PE } & 105 \\
\text { AE } & 107 \\
\text { AE } & 105 \\
\text { PE } & 107 \\
\end{array}$ & $\begin{array}{l}-1.616 \\
-1.629 \\
-1.617 \\
-1.617\end{array}$ & $\begin{array}{l}-1.133 \\
-1.132 \\
-1.136 \\
-1.130\end{array}$ & & & $\begin{array}{l}-1.938 \\
-1.939\end{array}$ & $\begin{array}{l}-1.124 \\
-1.132\end{array}$ \\
\hline $81-05(A)$ & $\begin{array}{l}S N-618 \\
S N-617 \\
S N-616 \\
S L-513 \\
S L-514 \\
S N-615\end{array}$ & $\begin{array}{l}-1.378 \\
-1.377 \\
-1.378 \\
-1.382 \\
-1.381 \\
-1.378\end{array}$ & $\begin{array}{l}-0.805 \\
-0.805 \\
-0.807 \\
-0.805 \\
-0.806 \\
-0.806\end{array}$ & $\begin{array}{l}-1.757 \\
-1.756 \\
-1.757 \\
-1.768 \\
-1.767 \\
-1.757\end{array}$ & $\begin{array}{l}-0.894 \\
-0.895 \\
-0.894 \\
-0.895 \\
-0.899 \\
-0.899\end{array}$ & $\begin{array}{l}-1.769 \\
-1.769\end{array}$ & $\begin{array}{l}-0.844 \\
-0.847\end{array}$ \\
\hline $81-05(B)$ & $\begin{array}{l}S L=512 \\
S L=511\end{array}$ & $\begin{array}{l}-1.394 \\
-1.383 \\
\end{array}$ & $\begin{array}{l}-0.806 \\
-0.807 \\
\end{array}$ & $\begin{array}{l}-1.792 \\
-1.771\end{array}$ & $\begin{array}{l}-0.901 \\
-0.900 \\
\end{array}$ & $\begin{array}{l}-1.820 \\
-1.789 \\
\end{array}$ & $\begin{array}{l}-0.854 \\
-0.859 \\
\end{array}$ \\
\hline $81-02(A)$ & $\begin{array}{l}S N-616 \\
S N-615 \\
S N-614 \\
S N-611 \\
S N-612 \\
S N-613\end{array}$ & $\begin{array}{l}-0.590 \\
-0.590 \\
-0.591 \\
-0.591 \\
-0.591 \\
-0.589\end{array}$ & $\begin{array}{l}-0.465 \\
-0.467 \\
-0.467 \\
-0.468 \\
-0.466 \\
-0.467\end{array}$ & & & $\begin{array}{l}-0.753 \\
-0.751\end{array}$ & $\begin{array}{l}-0.515 \\
-0.513\end{array}$ \\
\hline $81-02(B)$ & $\begin{array}{c}\text { SN-618 } \\
\text { SN-617 } \\
\text { DR }-712 \\
\text { DR }-713 \\
2^{\prime \prime} \text { FL }\end{array}$ & $\begin{array}{l}-0.588 \\
-0.586 \\
-0.589 \\
-0.590 \\
-0.589\end{array}$ & $\begin{array}{l}-0.467 \\
-0.466 \\
-0.441 \\
-0.465 \\
-0.466\end{array}$ & & & $\begin{array}{l}-0.753 \\
-0.751\end{array}$ & $\begin{array}{l}-0.517 \\
-0.514\end{array}$ \\
\hline
\end{tabular}


WHC-SD-WM-RPT-266, REV. 0

\begin{tabular}{|c|c|c|c|c|c|c|c|}
\hline \multirow{2}{*}{$\begin{array}{c}\text { Test } \\
\text { Station }\end{array}$} & \multirow{2}{*}{$\begin{array}{c}\text { Buried } \\
\text { Structure }\end{array}$} & \multicolumn{2}{|c|}{ July, 1994} & \multicolumn{2}{|c|}{ January, 1995} & \multicolumn{2}{|c|}{ August, 1995} \\
\hline & & ON & OFF & ON & OFF & ON & OFF \\
\hline $80-13(A)$ & $\begin{array}{c}\text { PW } 813 \\
1 N T \\
\text { ANN EXH } \\
\text { RW-N } \\
\text { RW-S } \\
\text { PW } 823 \\
\end{array}$ & $\begin{array}{l}-0.472 \\
-0.472 \\
-0.471 \\
-0.472 \\
-0.472 \\
-0.472 \\
\end{array}$ & $\begin{array}{l}-0.393 \\
-0.396 \\
-0.396 \\
-0.391 \\
-0.391 \\
-0.390 \\
\end{array}$ & & & $\begin{array}{l}-0.616 \\
-0.614\end{array}$ & $\begin{array}{l}-0.499 \\
-0.503\end{array}$ \\
\hline $80-13(B)$ & $\begin{array}{l}\text { SN-613 } \\
\text { SL-513 } \\
\end{array}$ & $\begin{array}{r}-0.474 \\
-0.474 \\
\end{array}$ & $\begin{array}{l}-0.392 \\
-0.392 \\
\end{array}$ & & & $\begin{array}{l}-0.616 \\
-0.620 \\
\end{array}$ & $\begin{array}{l}-0.503 \\
-0.504 \\
\end{array}$ \\
\hline $80-14$ & $\begin{array}{c}\text { INT } \\
\text { ANN EXH } \\
\text { PRI EXH } \\
\text { SN- } 613 \\
\text { SL-513 } \\
\end{array}$ & $\begin{array}{l}-2.212 \\
-2.212 \\
-2.210 \\
-2.212 \\
-2.212 \\
\end{array}$ & $\begin{array}{l}-1.096 \\
-1.092 \\
-1.087 \\
-1.091 \\
-1.089 \\
\end{array}$ & & & $\begin{array}{l}-2.750 \\
-2.751\end{array}$ & $\begin{array}{l}-1.138 \\
-1.148\end{array}$ \\
\hline $80-21$ & $\begin{array}{c}\text { PRI EXH } \\
\text { ANN EXH } \\
\text { SN- } 612 \\
\text { SL-512 } \\
\text { INT } \\
\end{array}$ & $\begin{array}{l}-1.805 \\
-1.835 \\
-1.813 \\
-1.838 \\
-1.802 \\
\end{array}$ & $\begin{array}{l}-1.103 \\
-1.101 \\
-1.103 \\
-1.102 \\
-1.103 \\
\end{array}$ & & & $\begin{array}{l}-3.449 \\
-3.453\end{array}$ & $\begin{array}{l}-1.766 \\
-1.766\end{array}$ \\
\hline $80-04$ & $\begin{array}{c}\text { SL-511 } \\
\text { INT-1 } \\
\text { ANN EXH } \\
\text { PRI EXH } \\
\text { INT-2 } \\
\text { SN-611 } \\
\end{array}$ & $\begin{array}{l}-1.450 \\
-1.449 \\
-1.449 \\
-1.449 \\
-1.450 \\
-1.451 \\
\end{array}$ & $\begin{array}{l}-0.758 \\
-0.755 \\
-0.759 \\
-0.756 \\
-0.757 \\
-0.761 \\
\end{array}$ & & & $\begin{array}{l}-1.579 \\
-1.574\end{array}$ & $\begin{array}{l}-0.833 \\
-0.827\end{array}$ \\
\hline $80-16$ & DR 714 & $\begin{array}{l}-1.276 \\
-1.273\end{array}$ & $\begin{array}{l}-1.000 \\
-1.007 \\
\end{array}$ & & & $\begin{array}{l}-1.706 \\
-1.705 \\
\end{array}$ & $\begin{array}{l}-1.102 \\
-1.095 \\
\end{array}$ \\
\hline
\end{tabular}


WHC-SD-WM-RPT-266, REV. 0

\begin{tabular}{|c|c|c|c|c|c|c|c|}
\hline \multirow{2}{*}{$\begin{array}{c}\text { Test } \\
\text { Station } \\
\end{array}$} & \multirow{2}{*}{$\begin{array}{c}\text { Buried } \\
\text { structure }\end{array}$} & \multicolumn{2}{|c|}{ July, 1994} & \multicolumn{2}{|c|}{ January, 1995} & \multicolumn{2}{|c|}{ August 1995} \\
\hline & & ON & OFF & ON & OFF & ON & OFF \\
\hline $33-36(1)$ & $\begin{array}{l}\text { IA \#2 } \\
\text { S- } 100 \\
\text { RW } \\
\text { IA } \# 3 \\
\text { PA }\end{array}$ & $\begin{array}{l}-1.114 \\
-1.111 \\
-1.109 \\
-1.114 \\
-1.115 \\
\end{array}$ & $\begin{array}{l}-0.678 \\
-0.684 \\
-0.677 \\
-0.680 \\
-0.682 \\
\end{array}$ & & & $\begin{array}{l}-1.367 \\
-1.363\end{array}$ & $\begin{array}{l}-1.055 \\
-1.058\end{array}$ \\
\hline $33-36(2)$ & $\begin{array}{c}\text { PA } \\
\text { IA } \\
1 / 2 " \# 1 \\
1 / 2 " \text { OA \#4 } \\
6 \text { CU LINES }\end{array}$ & $\begin{array}{l}-1.116 \\
-1.113 \\
-1.115 \\
-1.114 \\
-1.113 \\
\end{array}$ & $\begin{array}{l}-0.684 \\
-0.682 \\
-0.679 \\
-0.682 \\
-0.686 \\
\end{array}$ & & & $\begin{array}{l}-1.384 \\
-1.380\end{array}$ & $\begin{array}{l}-1.042 \\
-1.059\end{array}$ \\
\hline $33-34$ & $\begin{array}{c}\mathrm{DR}-371 \\
\mathrm{RW}\end{array}$ & & & & & $\begin{array}{r}-1.930 \\
-1.914 \\
\end{array}$ & $\begin{array}{r}-1.390 \\
-1.382 \\
\end{array}$ \\
\hline $33-35$ & $\begin{array}{l}\text { SL-167 } \\
\text { SL-168 } \\
\text { SN-219 } \\
\text { SN-269 } \\
\text { SN-270 } \\
\text { SN-220 } \\
\end{array}$ & $\begin{array}{l}-2.037 \\
-2.036 \\
-2.037 \\
-2.038 \\
-2.048 \\
-2.038 \\
\end{array}$ & $\begin{array}{l}-1.099 \\
-1.099 \\
-1.092 \\
-1.088 \\
-1.091 \\
-1.102 \\
\end{array}$ & & & $\begin{array}{l}-1.929 \\
-1.929\end{array}$ & $\begin{array}{l}-1.391 \\
-1.393\end{array}$ \\
\hline $77-01(\# 1)$ & $\begin{array}{c}S N-610 \\
S N-609 \\
\text { V005 } \\
\text { V007 } \\
\end{array}$ & $\begin{array}{l}-2.287 \\
-2.286 \\
-2.285 \\
-2.284 \\
\end{array}$ & $\begin{array}{l}-1.169 \\
-1.167 \\
-1.165 \\
-1.166 \\
\end{array}$ & & & $\begin{array}{l}-2.542 \\
-2.548\end{array}$ & $\begin{array}{l}-1.268 \\
-1.272\end{array}$ \\
\hline $77-01(\# 2)$ & $\begin{array}{l}S L-510 \\
S L-509 \\
D R-374 \\
\end{array}$ & $\begin{array}{l}-2.283 \\
-2.288 \\
-2.287 \\
\end{array}$ & $\begin{array}{l}-1.171 \\
-1.168 \\
-1.167 \\
\end{array}$ & & & $\begin{array}{l}-2.546 \\
-2.546\end{array}$ & $\begin{array}{l}-1.271 \\
-1.270\end{array}$ \\
\hline $33-02$ & $\begin{array}{l}\text { DR } 374 \\
\text { v005 } \\
\text { v007 } \\
\end{array}$ & $\begin{array}{l}-1.091 \\
-1.092 \\
\end{array}$ & $\begin{array}{r}-0.778 \\
-0.780 \\
\end{array}$ & $\begin{array}{l}-1.237 \\
-1.247\end{array}$ & $\begin{array}{l}-0.786 \\
-0.786\end{array}$ & $\begin{array}{l}-1.237 \\
-1.247\end{array}$ & $\begin{array}{l}-0.786 \\
-0.786\end{array}$ \\
\hline $33-12$ & $\begin{array}{c}\text { 8" EXH } \\
\text { DR } 361 \\
\text { IA }\end{array}$ & $\begin{array}{l}-1.093 \\
-1.092\end{array}$ & $\begin{array}{l}-0.782 \\
-0.782\end{array}$ & & & $\begin{array}{r}-1.248 \\
-1.241 \\
\end{array}$ & $\begin{array}{l}-0.784 \\
-0.783 \\
\end{array}$ \\
\hline $33-32(\# 1)$ & $\begin{array}{c}\text { DR } 361 \\
\text { 10"1 INTAKE } \\
\text { IA-A } \\
\text { SN-268 } \\
\text { IA-B } \\
\text { IA-C } \\
\end{array}$ & $\begin{array}{l}-0.966 \\
-0.961\end{array}$ & $\begin{array}{l}-0.709 \\
-0.702\end{array}$ & $\begin{array}{l}-2.253 \\
-2.254 \\
-2.251 \\
-2.253 \\
-2.251 \\
-2.252 \\
\end{array}$ & $\begin{array}{l}-1.076 \\
-1.082 \\
-1.076 \\
-1.076 \\
-1.070 \\
-1.074 \\
\end{array}$ & $\begin{array}{l}-1.233 \\
-1.234\end{array}$ & $\begin{array}{l}-0.792 \\
-0.793\end{array}$ \\
\hline $33-32(\# 2)$ & $\begin{array}{c}10 " \text { EXH } \\
\text { PA } \\
\text { IA-A } \\
\text { IA-B } \\
\text { SN-267 } \\
\end{array}$ & -0.966 & -0.708 & & & $\begin{array}{l}-1.234 \\
-1.235\end{array}$ & $\begin{array}{l}-0.795 \\
-0.790\end{array}$ \\
\hline $33-30$ & $\begin{array}{l}\text { DR } 361 \\
S N-262 \\
S L-162 \\
\text { IA } \\
\text { I" EXH } \\
\end{array}$ & $\begin{array}{l}-1.672 \\
-1.670\end{array}$ & $\begin{array}{l}-0.913 \\
-0.915\end{array}$ & & & $\begin{array}{r}-2.059 \\
-2.065 \\
\end{array}$ & $\begin{array}{l}-0.994 \\
-0.994 \\
\end{array}$ \\
\hline
\end{tabular}


WHC-SD-WM-RPT-266, REV. 0

\begin{tabular}{|c|c|c|c|c|c|c|c|}
\hline \multirow{2}{*}{$\begin{array}{c}\text { Test } \\
\text { Station }\end{array}$} & \multirow{2}{*}{$\begin{array}{c}\text { Buried } \\
\text { Structure }\end{array}$} & \multicolumn{2}{|c|}{ July, 1994} & \multicolumn{2}{|c|}{ January, 1995} & \multicolumn{2}{|c|}{ August, 1995} \\
\hline & & ON & OFF & ON & OFF & ON & OFF \\
\hline $33-32$ & $\begin{array}{c}S-100 \\
S L-167 \\
S N-219 \\
2 N-268 \\
\end{array}$ & $\begin{array}{r}-1.116 \\
-1.117 \\
\end{array}$ & $\begin{array}{l}-0.775 \\
-0.775 \\
\end{array}$ & & & $\begin{array}{l}-1.427 \\
-1.429\end{array}$ & $\begin{array}{l}-0.876 \\
-0.876\end{array}$ \\
\hline $33-47$ & $\begin{array}{l}\text { SL-509 } \\
\text { SL-164 } \\
\text { SL- } 166 \\
\text { SL-510 } \\
\end{array}$ & $\begin{array}{l}-1.325 \\
-1.322 \\
-1.322 \\
-1.324 \\
\end{array}$ & $\begin{array}{l}-0.703 \\
-0.699 \\
-0.700 \\
-0.705 \\
\end{array}$ & & & $\begin{array}{l}-1.934 \\
-1.930\end{array}$ & $\begin{array}{l}-0.916 \\
-0.915\end{array}$ \\
\hline $77-04$ & 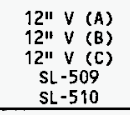 & $\begin{array}{l}-1.319 \\
-1.319 \\
-1.316 \\
-1.322 \\
-1.321 \\
\end{array}$ & $\begin{array}{l}-0.757 \\
-0.757 \\
-0.750 \\
-0.760 \\
-0.758 \\
\end{array}$ & & & $\begin{array}{l}-1.655 \\
-1.653\end{array}$ & $\begin{array}{l}-0.866 \\
-0.865\end{array}$ \\
\hline $33-14$ & $\begin{array}{l}\text { PW } 464 \\
\text { PW-474 } \\
10 " \text { EXH } \\
\end{array}$ & $\begin{array}{l}-0.888 \\
-0.888\end{array}$ & $\begin{array}{l}-0.661 \\
-0.664\end{array}$ & & & $\begin{array}{l}-0.697 \\
-0.699\end{array}$ & $\begin{array}{l}-0.541 \\
-0.544\end{array}$ \\
\hline $33-15$ & $\begin{array}{c}\text { SN-274 } \\
10 " 1 \text { EXH } \\
\text { SL-164 } \\
\text { SN-264 } \\
\end{array}$ & $\begin{array}{l}-0.888 \\
-0.889 \\
\end{array}$ & $\begin{array}{l}-0.657 \\
-0.661 \\
\end{array}$ & & & $\begin{array}{l}-0.700 \\
-0.700\end{array}$ & $\begin{array}{l}-0.542 \\
-0.543\end{array}$ \\
\hline $33-24$ & $\begin{array}{c}12^{\prime \prime} \text { VENT } \\
14^{\prime \prime} \text { VENT } \\
\text { SL-166 } \\
\text { SN-266 }\end{array}$ & $\begin{array}{l}-0.957 \\
-0.959 \\
\end{array}$ & $\begin{array}{l}-0.537 \\
-0.542 \\
\end{array}$ & & & $\begin{array}{l}-1.272 \\
-1.273\end{array}$ & $\begin{array}{l}-0.657 \\
-0.654\end{array}$ \\
\hline $33-07$ & $\begin{array}{l}10 " \text { EXH } \\
\text { PW } 476 \\
\text { PW } 466 \\
\end{array}$ & $\begin{array}{l}-0.527 \\
-0.527 \\
-0.528 \\
\end{array}$ & $\begin{array}{l}-0.396 \\
-0.398 \\
-0.398 \\
\end{array}$ & & & $\begin{array}{l}-0.744 \\
-0.746\end{array}$ & $\begin{array}{l}-0.500 \\
-0.506\end{array}$ \\
\hline $33-08$ & $\begin{array}{l}\text { SL- } 166 \\
\text { SN-266 }\end{array}$ & $\begin{array}{l}-0.483 \\
-0.483\end{array}$ & $\begin{array}{l}-0.392 \\
-0.392\end{array}$ & & & $\begin{array}{l}-0.748 \\
-0.748\end{array}$ & $\begin{array}{l}-0.508 \\
-0.506\end{array}$ \\
\hline $33-23$ & $\begin{array}{c}\text { 8" INTAKE } \\
\text { SN-266 } \\
\text { SL-166 }\end{array}$ & $\begin{array}{l}-0.815 \\
-0.813 \\
\end{array}$ & $\begin{array}{r}-0.452 \\
-0.447 \\
\end{array}$ & $\begin{array}{l}-1.597 \\
-1.599 \\
-1.600 \\
\end{array}$ & $\begin{array}{l}-0.750 \\
-0.753 \\
-0.753 \\
\end{array}$ & $\begin{array}{l}-1.029 \\
-1.031\end{array}$ & $\begin{array}{l}-0.560 \\
-0.560\end{array}$ \\
\hline 33-05 & $\begin{array}{l}\text { PW } 465 \\
\text { PH } 475\end{array}$ & $\begin{array}{l}-0.470 \\
-0.470 \\
\end{array}$ & $\begin{array}{l}-0.372 \\
-0.372 \\
\end{array}$ & & & $\begin{array}{l}-0.452 \\
-0.454 \\
\end{array}$ & $\begin{array}{l}-0.368 \\
-0.368 \\
\end{array}$ \\
\hline $33-42(\# 1)$ & $\begin{array}{c}14 " \text { EXH } \\
12 " \text { EXH } \\
12 " \text { M42 EXH } \\
\text { SL-165 } \\
\end{array}$ & $\begin{array}{l}-1.486 \\
-1.486 \\
-1.488 \\
-1.485 \\
\end{array}$ & $\begin{array}{l}-0.593 \\
-0.592 \\
-0.592 \\
-0.593 \\
\end{array}$ & & & $\begin{array}{l}-1.806 \\
-1.807\end{array}$ & $\begin{array}{l}-0.720 \\
-0.723\end{array}$ \\
\hline $33-42(\# 2)$ & 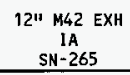 & $\begin{array}{l}-1.484 \\
-1.486 \\
-1.486 \\
\end{array}$ & $\begin{array}{l}-0.593 \\
-0.592 \\
-0.592 \\
\end{array}$ & & & $\begin{array}{l}-1.808 \\
-1.807\end{array}$ & $\begin{array}{l}-0.723 \\
-0.723\end{array}$ \\
\hline $33-11$ & $\begin{array}{c}\text { IA } \\
\text { 6" UNKNOWN } \\
5-1 / 2 " 1 \text { CU } \\
\text { SL-165 } \\
\text { SN-265 } \\
10^{\prime \prime} \text { EXH }\end{array}$ & $\begin{array}{l}-1.604 \\
-1.593\end{array}$ & $\begin{array}{l}-0.761 \\
-0.762\end{array}$ & $\begin{array}{l}-3.820 \\
-3.821 \\
-3.820 \\
-3.825 \\
-3.827 \\
-3.823\end{array}$ & $\begin{array}{l}-1.163 \\
-1.161 \\
-1.156 \\
-1.169 \\
-1.160 \\
-1.161\end{array}$ & $\begin{array}{l}1.900 \\
-1.901\end{array}$ & $\begin{array}{l}-0.878 \\
-0.879\end{array}$ \\
\hline
\end{tabular}


WHC-SD-WM-RPT-266, REV. 0

\begin{tabular}{|c|c|c|c|c|c|c|c|}
\hline \multirow{2}{*}{$\begin{array}{c}\text { Test } \\
\text { Station }\end{array}$} & \multirow{2}{*}{$\begin{array}{c}\text { Buried } \\
\text { Structure }\end{array}$} & \multicolumn{2}{|c|}{ July, 1994} & \multicolumn{2}{|c|}{ January, 1995} & \multicolumn{2}{|c|}{ August, 1995} \\
\hline & & ON & OFF & ON & OFF & ON & OFF \\
\hline $33-28(\# 1)$ & $\begin{array}{c}7-1 / 2^{\prime \prime} \text { AIR (A) } \\
7-1 / 2^{\prime \prime} \text { AIR (B) } \\
7-1 / 2^{\prime \prime} \text { AIR (C) } \\
\text { SL-165 } \\
\text { SN-263 } \\
\end{array}$ & $\begin{array}{r}-1.545 \\
-1.542 \\
\end{array}$ & $\begin{array}{r}-0.996 \\
-0.995 \\
\end{array}$ & & & $\begin{array}{l}-2.495 \\
-2.496\end{array}$ & $\begin{array}{l}-1.277 \\
-1.277\end{array}$ \\
\hline $33-28(\# 2)$ & $\begin{array}{c}\text { IA } \\
12 " \text { VENT } \\
1 / 2 " \text { AIR } \\
\text { SN-265 } \\
\end{array}$ & -1.546 & -0.995 & & & $\begin{array}{l}-2.494 \\
-2.495\end{array}$ & $\begin{array}{l}-1.270 \\
-1.274\end{array}$ \\
\hline $33-16$ & $\begin{array}{c}\text { SL-510 } \\
\text { SL-165 } \\
\text { SL-161 } \\
\text { DRAIN } 361 \\
\text { SL }=163 \\
\end{array}$ & $\begin{array}{l}-0.820 \\
-0.821\end{array}$ & $\begin{array}{l}-0.577 \\
-0.578\end{array}$ & & & $\begin{array}{l}-0.654 \\
-0.655\end{array}$ & $\begin{array}{l}-0.406 \\
-0.404\end{array}$ \\
\hline $33-17$ & $\begin{array}{l}\text { SL-168 } \\
\text { SN-220 } \\
\text { SN-267 } \\
\end{array}$ & $\begin{array}{l}-0.822 \\
-0.822\end{array}$ & $\begin{array}{l}-0.575 \\
-0.579\end{array}$ & & & $\begin{array}{l}-0.657 \\
-0.657\end{array}$ & $\begin{array}{l}-0.403 \\
-0.402\end{array}$ \\
\hline $33-25$ & $\begin{array}{c}10 " \text { EXH } \\
\text { SN-261 } \\
\text { SL-161 } \\
\end{array}$ & $\begin{array}{l}-1.026 \\
-1.024 \\
\end{array}$ & $\begin{array}{l}-0.543 \\
-0.542 \\
\end{array}$ & & & $\begin{array}{l}-1.525 \\
-1.526\end{array}$ & $\begin{array}{l}-0.654 \\
-0.651\end{array}$ \\
\hline $33-26$ & $\begin{array}{c}\text { IA } \\
P W-471 \\
P W-461 \\
\end{array}$ & $\begin{array}{r}-1.022 \\
-1.025 \\
\end{array}$ & $\begin{array}{l}-0.537 \\
-0.543 \\
\end{array}$ & & & $\begin{array}{l}-1.524 \\
-1.524\end{array}$ & $\begin{array}{l}-0.650 \\
-0.650\end{array}$ \\
\hline $33-27(\# 1)$ & $\begin{array}{l}\text { SN-220 } \\
\text { SL-167 } \\
\text { SL-168 } \\
\text { SN-219 } \\
\end{array}$ & $\begin{array}{l}-1.446 \\
-1.442 \\
-1.444 \\
-1.443 \\
\end{array}$ & $\begin{array}{l}-0.766 \\
-0.766 \\
-0.769 \\
-0.766 \\
\end{array}$ & & & $\begin{array}{l}-1.873 \\
-1.874\end{array}$ & $\begin{array}{l}-0.900 \\
-0.900\end{array}$ \\
\hline $33-27(\# 2)$ & $\begin{array}{c}\text { IA } \\
\text { SN-270 } \\
\text { SN-269 }\end{array}$ & -1.448 & -0.759 & & & $\begin{array}{l}-1.868 \\
-1.874\end{array}$ & $\begin{array}{l}-0.899 \\
-0.900\end{array}$ \\
\hline
\end{tabular}

The measured potentials in both tank farms were observed at a more negative value than the potentials which were recorded during the baseline survey. The rectifiers' tap setting were adjusted after the baseline survey of 1994 . All the structures in AP farm that were tested and all but four of the structures in AW farm that were tested were protected to one of the following criteria: a more negative potential than -0.85 volts; a polarization voltage of at least 100 millivolts more negative than the $7 / 94$ survey potentials; or 100 millivolts polarization more negative than the native potentials. No adjustments were made to rectifiers R1 and R2. These rectifiers serve AP farm. The four structures in AW farm receiving less than 100 millivolts of polarization were polarizing to between 66 to 79 millivolts. Rectifier 19 was not adjusted to a higher tap setting. This rectifier was already running at its maximum amperage. 
WHC-SD-WM-RPT-265, REV. 0

\subsection{PUREX Facility}

The PUREX cathodic protection (CP) system associated with Rectifier 2 was surveyed per Engineering Task P1an PUREX Cathodic Protection System Maintenance (WHC-SD-WM-ETP-146). The PUREX annual survey requires coordination with Tank Farms to install test equipment on the nearby rectifiers that may affect each other by inadvertent stray currents.

The CP system provides corrosion protection to PUREX's underground transfer lines V021, V022, V023 and V714. Besides these lines, other lines in the vicinity may be electrically connected to the system and may be picking up protective $C P$ currents.

In addition to Rectifier 2, pulse generators were also installed on Tank Farm's Rectifiers 19, RI and R2. These rectifiers, pulsing in synch with Rectifier 2, interrupt all nearby underground currents that may influence the measured potentials. The instant "OFF" (polarized) potentials provide an accurate assessment of the degree of corrosion protection provided to the buried transfer lines.

These tests were performed on August 7 and 25, 1995 by PUREX Electrical Maintenance with support from TWRS M\&CE. A wave form analyzer (WFA) was used to measure the "ON"/ OFF" potentials. The WFA captures both the high and low pipeto-soil potentials representative of the on/off cycles of the pulse generators.

\section{SURVEY RESULTS AND DISCUSSION}

Rectifier 2, a standard oil-filled rectifier operating at constant voltage, was visually inspected and found in good condition. The rectifier oil appeared clean, in good condition, and at the proper level. No oil leaks from the rectifier were found. The operational characteristics of Rectifier 2 prior to performing the survey are provided below:

\section{Rectifier 2}

Make: Good-All Electric

Model: CSOYSF 120-65 ENTZ

Serial \#: $85 \mathrm{C} 2338$

Part \#: 0030095

Rectifier Input: 480 volts (AC), 11.1 amps

Maximum Rectifier Output: 120 volts (DC), 65 amps

Taps (as found): C-3

Rectifier Output:

Current (as found):

$\begin{array}{cc}\text { Panel Readings } & \text { Meter (Portable) Readings } \\ 88 \mathrm{VDC} & 87.5 \mathrm{VDC} \\ 31 \text { amps } & 30 \mathrm{amps}\end{array}$

Shunt: 100 amps 50 mVolts 
Before performing the survey, key test stations behind 202A Building were selected for testing. The key test stations represent the entire length of the protected transfer lines. The pipe-to-soil potentials were measured with a portable reference cell rather than the permanent reference cells that are installed in each test station. The portable reference cell was considered more accurate than the older deteriorating permanent cells.

The results of the survey are presented in Table 4 with the initial tap settings set at $\mathrm{C}-3$. These results are compared to those measured during the baseline $C P$ survey $(6 / 94)$. The baseline tap settings were set at A-4.

Although the measured potentials became more negative when compared to the baseline survey potentials, the potentials at most test stations did not meet the -0.85 volt criteria. Following the survey, the tap settings were changed from $\mathrm{C}-3$ to $\mathrm{D}-2$ and the system was allowed to re-stabilize for two weeks. Afterwards, several test stations were reevaluated. The results of these tests are also presented in Table 4.

\begin{tabular}{|c|c|c|c|c|c|c|c|}
\hline & Table 4 & ipe-t & 1 Pot & ials & ),$P($ & & \\
\hline \multirow{2}{*}{$\begin{array}{c}\text { Test } \\
\text { station }\end{array}$} & \multirow{2}{*}{$\begin{array}{l}\text { Buried } \\
\text { structure }\end{array}$} & \multicolumn{2}{|c|}{ Taps@ A-4 } & \multicolumn{2}{|c|}{ Taps a $\mathrm{C}-3$} & \multicolumn{2}{|c|}{ Taps a D-2 } \\
\hline & & $\mathrm{ON}$ & OFF & ON & OFF & ON & ofF \\
\hline \multirow{2}{*}{$\begin{array}{c}35-08 \\
(2)\end{array}$} & V714 & -0.544 & -0.474 & -0.783 & -0.570 & & \\
\hline & $24 " 8823$ (1) & -0.526 & -0.474 & -0.744 & -0.561 & & \\
\hline \multirow{3}{*}{$\begin{array}{c}35-09 \\
\text { (2) }\end{array}$} & V714 (sleeve) & -0.126 & -0.083 & -0.386 & -0.233 & -0.366 & -0.258 \\
\hline & 3" T053 (1) & -0.522 & -0.467 & -0.746 & -0.564 & -0.725 & -0.565 \\
\hline & $16^{\prime \prime} 8824$ (1) & -0.526 & -0.469 & -0.746 & -0.563 & -0.732 & -0.568 \\
\hline \multirow[t]{5}{*}{$35-11$} & $2^{11} \mathrm{~F} 602$ (1) & -0.349 & -0.320 & -0.453 & -0.390 & & \\
\hline & $24^{\prime \prime} 8823(1)$ & -0.349 & -0.324 & -0.469 & -0.399 & & \\
\hline & 2" F127 (1) & -0.349 & -0.321 & -0.475 & -0.403 & & \\
\hline & 6" Vent (1) & -0.346 & -0.322 & -0.479 & -0.411 & & \\
\hline & 4" Vent (1) & -0.348 & -0.321 & -0.483 & -0.413 & & \\
\hline $35-12$ & $16 " 8824$ (1) & -0.638 & -0.531 & -1.311 & -0.901 & -1.371 & -0.931 \\
\hline
\end{tabular}


WHC-SD-WM-RPT-266, REV. 0

\begin{tabular}{|c|c|c|c|c|c|c|c|}
\hline \multirow{3}{*}{$\begin{array}{c}\text { Test } \\
\text { Station }\end{array}$} & Table 4 & ipe-to & $11 \mathrm{Po}$ & tials & C), & & \\
\hline & \multirow{2}{*}{$\begin{array}{l}\text { Buried } \\
\text { structure }\end{array}$} & \multicolumn{2}{|c|}{ Tapsa A-4 } & \multicolumn{2}{|c|}{ Taps a $c-3$} & \multicolumn{2}{|c|}{ Taps a D-2 } \\
\hline & & ON & OFF & ON & OFF & ON & ofF \\
\hline \multirow{5}{*}{$\begin{array}{c}35-08 \\
(2)\end{array}$} & V714 & -0.544 & -0.474 & -0.783 & -0.570 & & \\
\hline & 4" WRAP (1) & -0.637 & -0.536 & -1.310 & -0.907 & -1.377 & -0.933 \\
\hline & 6" $S C-B Y(1)$ & -0.636 & -0.535 & -1.307 & -0.910 & -1.375 & -0.937 \\
\hline & 3" AMMONIA (1) & -0.632 & -0.536 & -1.274 & -0.911 & -1.332 & -0.936 \\
\hline & $12 " \mathrm{SC} H D R(1)$ & -0.638 & -0.532 & -1.312 & -0.913 & -1.388 & -0.939 \\
\hline \multirow[t]{6}{*}{$35-20$} & v022 & -0.725 & -0.479 & -1.098 & -0.614 & & \\
\hline & v021 & -0.732 & -0.483 & -1.103 & -0.616 & & \\
\hline & V714 & -0.735 & -0.481 & -1.115 & -0.617 & & \\
\hline & v023 & -0.728 & -0.481 & -1.096 & -0.615 & & \\
\hline & g" UI SW (1) & -0.686 & -0.469 & -0.968 & -0.592 & & \\
\hline & $2 " 060$ (1) & -0.714 & -0.476 & -1.066 & -0.603 & & \\
\hline \multirow[t]{3}{*}{$35-25$} & v022 & -0.527 & -0.445 & -0.951 & -0.656 & -0.831 & -0.600 \\
\hline & v021 & -0.523 & -0.439 & -0.955 & -0.657 & -0.834 & -0.604 \\
\hline & V714 & -0.531 & -0.443 & -0.966 & -0.657 & -0.844 & -0.602 \\
\hline \multirow[t]{2}{*}{$35-25$} & v023 & -0.531 & -0.442 & -0.959 & -0.659 & -0.828 & -0.600 \\
\hline & $30 " 8023$ (1) & -0.528 & -0.438 & -0.925 & -0.651 & -0.791 & -0.590 \\
\hline \multirow[t]{4}{*}{$35-40$} & 3'M21 & -0.520 & -0.449 & -0.868 & -0.636 & & \\
\hline & 6" VENT (1) & -0.516 & -0.441 & -0.875 & -0.641 & & \\
\hline & 4" W-LINE (1) & -0.516 & -0.440 & -0.881 & -0.647 & & \\
\hline & RW-M5 (1) & -0.515 & -0.444 & -0.890 & -0.651 & & \\
\hline
\end{tabular}


WHC-SD-WM-RPT-266, REV. 0

\begin{tabular}{|c|c|c|c|c|c|c|c|}
\hline \multirow{2}{*}{$\begin{array}{c}\text { Test } \\
\text { Station }\end{array}$} & \multirow{2}{*}{$\begin{array}{l}\text { suried } \\
\text { structure }\end{array}$} & \multicolumn{2}{|c|}{ Tapsa A-4 } & \multicolumn{2}{|c|}{ Taps a c-3 } & \multicolumn{2}{|c|}{ Taps a $D-2$} \\
\hline & & ON & OFF & ON & OFF & ON & OFF \\
\hline $\begin{array}{c}35-08 \\
(2)\end{array}$ & V714 & -0.544 & -0.474 & -0.783 & -0.570 & & \\
\hline \multirow[t]{3}{*}{$35-41$} & 12" SC HDR (1) & -0.516 & -0.442 & -0.893 & -0.657 & -1.081 & -0.728 \\
\hline & 6" SC BY (1) & -0.515 & -0.446 & -0.892 & -0.656 & -1.093 & -0.744 \\
\hline & 3" AMMONIA (1) & -0.511 & -0.445 & -0.891 & -0.663 & -1.032 & -0.716 \\
\hline \multirow[t]{2}{*}{$35-54$} & $30 " 8823(1)$ & -0.325 & -0.324 & -0.479 & -0.416 & -0.450 & -0.394 \\
\hline & 4"M21 (1) & -0.325 & -0.324 & -0.480 & -0.416 & -0.449 & -0.396 \\
\hline \multirow[t]{5}{*}{$35-60$} & v022 & -0.605 & -0.513 & -0.907 & -0.677 & & \\
\hline & v021 & -0.605 & -0.512 & -0.909 & -0.678 & & \\
\hline & V714 & -0.610 & -0.516 & -0.925 & -0.681 & & \\
\hline & v023 & -0.606 & -0.512 & -0.915 & -0.679 & & \\
\hline & T144 (1) & -0.586 & -0.509 & -0.882 & -0.672 & & \\
\hline \multirow[t]{2}{*}{$35-61$} & v714 & -0.390 & -0.359 & -0.776 & -0.592 & & \\
\hline & $1-1 / 2^{\prime \prime}$ SCH 40 (1) & -0.376 & -0.355 & -0.736 & -0.590 & & \\
\hline
\end{tabular}

(1) Per SD-WM-TI-276, Rev. 0, "Project B-234, Upgrade of Hanford site 200 Areas Cathodic Protection Systems, final Energization Report" these lines are reportedly not protected by the installed cathodic protection system.

(2) At test stations 35-08 and 35-09 the transfer line v714 is located within a sleeve and insulated from the sleeve with insulating spacers. The test leads are attached to the sleeve rather than to V714 transfer line resulting in more positive pipe-to-soil potential readings at these test stations. 
WHC-SD-WM-RPT-266, REV. 0

The data in Table 4 shows that the transfer lines in Test Station 35-12 meet the -0.85 volt criteria. These lines were reported in project documentation as those not required nor intended to be protected by the CP system. These lines may not be intentionally bonded into the system and could be picking up stray currents. At most of the other test stations a potential shift of 100 $\mathrm{mV}$ on the piping was observed when the tap settings were changed from $\mathrm{A}-4$ to C-3 and from A-4 to D-2. This shows that corrosion protection of these 1 ines is provided per the $100 \mathrm{mV}$ potential shift criteria. The lines not intentionally designed to be protected may be picking up stray currents if the lines are not bonded. However it is difficult to ascertain without further investigation. In test station 35-20, the 8" UI-SW line appears to be picking up stray current due to the more positive "OFF" potential relative to the other pipes.

Increasing the electrical output from the rectifier was deemed unlikely to polarize the potentials on the piping to a value as negative or more negative than the -0.85 volt criteria. The small differences observed in the "ON" and "OFF" potentials at test stations 35-11 and 35-54 show that these lines are not protected and are picking up almost no current.

\subsection{West Tank Farms}

The CP system in West Tank Farms is comprised of several subsystems. These subsystems are integrated into the West Area Tank Farm CP system. The protected transfer lines are largely electrically continuous. Some of the transfer 1 ines run between farms and subsystems. Each subsystem consists of a rectifier unit, associated cables, anodes, and test stations.

There are a total of 13 rectifiers in 200 West Area. Ten rectifiers are owned by West Tank Farm Operations, two rectifiers are owned by 222-S Labs, and one rectifier is owned by the Plutonium Finishing PTant (PFP). Two new rectifiers were installed in early 1996, one at 241-SY Tank Farm and one at 222-S Labs. Table 5 lists the operational rectifiers at 1995 year-end in West Area Tank Farms and identifies the transfer lines protected. Rectifier 36 at 241-SY was brought online in January 1996. Document WHC-SD-430-0TR-001 Rev. 0, Operational Test Report for Project W-430, SY Farm Cathodic Protection, presents the performance of Rectifier 36. 
WHC-SD-WM-RPT-266, REV. 0

\begin{tabular}{|c|c|c|}
\hline RECTIF IER & LOCATION & PROTECTED SYSIEM \\
\hline 22 & PFP, outside east fence & Lines $202 / 203$ from PFP to $241-T X$ Tank Farm \\
\hline 23 & Northwest Corner of $\mathrm{TX}$ & Lines 202/203 from PFP to 241-TX Tank Farm \\
\hline 24 & 16 th and Camden & 241-U-151 Diversion Box and assoc. lines \\
\hline 25 & 16th and Canden & Transfer lines from 242 Evap to 241-U Tank Farm \\
\hline 26 & North of 241-sr & $\begin{array}{l}\text { Lines from } 242-s \text { to } S-152 \text { and SL-175, }-176 \text { to } \\
241-s y\end{array}$ \\
\hline 27 & NE of S-151 Diversion box & 244-S Saltwell Receiver and S- 151 Diversion Box to 241-sY \\
\hline 34 & $S$ of $T X-152$ Diversion box & Process lines surrounding TX-152 Diversion box \\
\hline 35 & 16th and Camden & Process lines from $C$ and $D$ valve pits and $244-U$ Vault \\
\hline 36 & North of 241-sY & Process lines in $241-\mathrm{sy}$ \\
\hline 37 & North of $242-T$ & Lines to/from 244-TX Saltwell Receiver \\
\hline
\end{tabular}

\section{SURVEY RESULTS}

At the time of the survey, all rectifiers were found operating with the electrical output characteristics presented in Table 6 . Historical rectifier outputs from July 1994 and January 1995 surveys are also provided for comparison. All of the rectifiers were found to be in good physical condition. The rectifier oil was found clean and no significant gasket rips were noted.

Variations in the rectifier outputs are noted from the data that is presented in Table 6 . The changes in the rectifier outputs are largely due to the rectifier tap setting adjustments that were made following the July 1994 surveys. However, there are some variations in output without rectifier adjustments. These variations can be caused by a number of factors such as soil composition fluctuations (moisture), decreased coating integrity, and an aging $C P$ system. 
WHC-SD-WM-RPT-266, REV. 0

\begin{tabular}{|c|c|c|c|c|}
\hline \multicolumn{2}{|c|}{ Table 6} & \multicolumn{3}{|c|}{ Tank Farm Rectifier Output (volt/amp) } \\
\hline RECTIFIER & JULY 1994 & JANUARY 1995 & JUNE 1995 & ADJUSTMENTS ${ }^{(3)}$ \\
\hline 22 & $115 / 7.4$ & $136 / 7.4$ & $N / A$ & $D-2$ to $\max (D-5)$ \\
\hline 23 & $91.4 / 11.8$ & $85.9 / 8.0$ & $86.6 / 12$ & None \\
\hline 24 & $46.5 / 4.5$ & Not operational & $54 / 4.5$ & $B-2$ to $B-3$ \\
\hline 25 & $66.8 / 6$ & Not operational & $67.6 / 8$ & None \\
\hline 26 & $40 / 5.2$ & $40 / 5.2$ & $39.3 / 5.2$ & None \\
\hline 27 & $69.6 / 2.9$ & Not accessible & $142 / 3$ & $B-5$ to $\max (D-5)$ \\
\hline 34 & $21.5 / 0.5$ & $31.4 / 0.6$ & $31.2 / 0.8^{(1)}$ & $A-5$ to $B-2$ \\
\hline 35 & $11.5 / 3.7$ & Not operational & $14.6 / 2.4$ & $B-1$ to $B-2$ \\
\hline 37 & $8 / 3.7$ & $10.2 / 3.6$ & $10.2 / 3.8^{(2)}$ & $A-4$ to $A-5$ \\
\hline
\end{tabular}

(1) Rectifier tap settings changed to B-5 following the June 1995 surveys. Rectifier output increased to $40 \mathrm{~V}, 1.2 \mathrm{~A}$.

(2) Rectifier tap settings changed to B-2 following the June 1995 surveys. Rectifier output increased to $15 \mathrm{~V}, 6 \mathrm{~A}$.

(3) Adjustments made following the July 1994 survey.

The results of key test stations surveys are presented in Table 7 . Results from earlier surveys in June 1994 and January 1995 are also provided. 
WHC-SD-WM-RPT-266, REV. 0

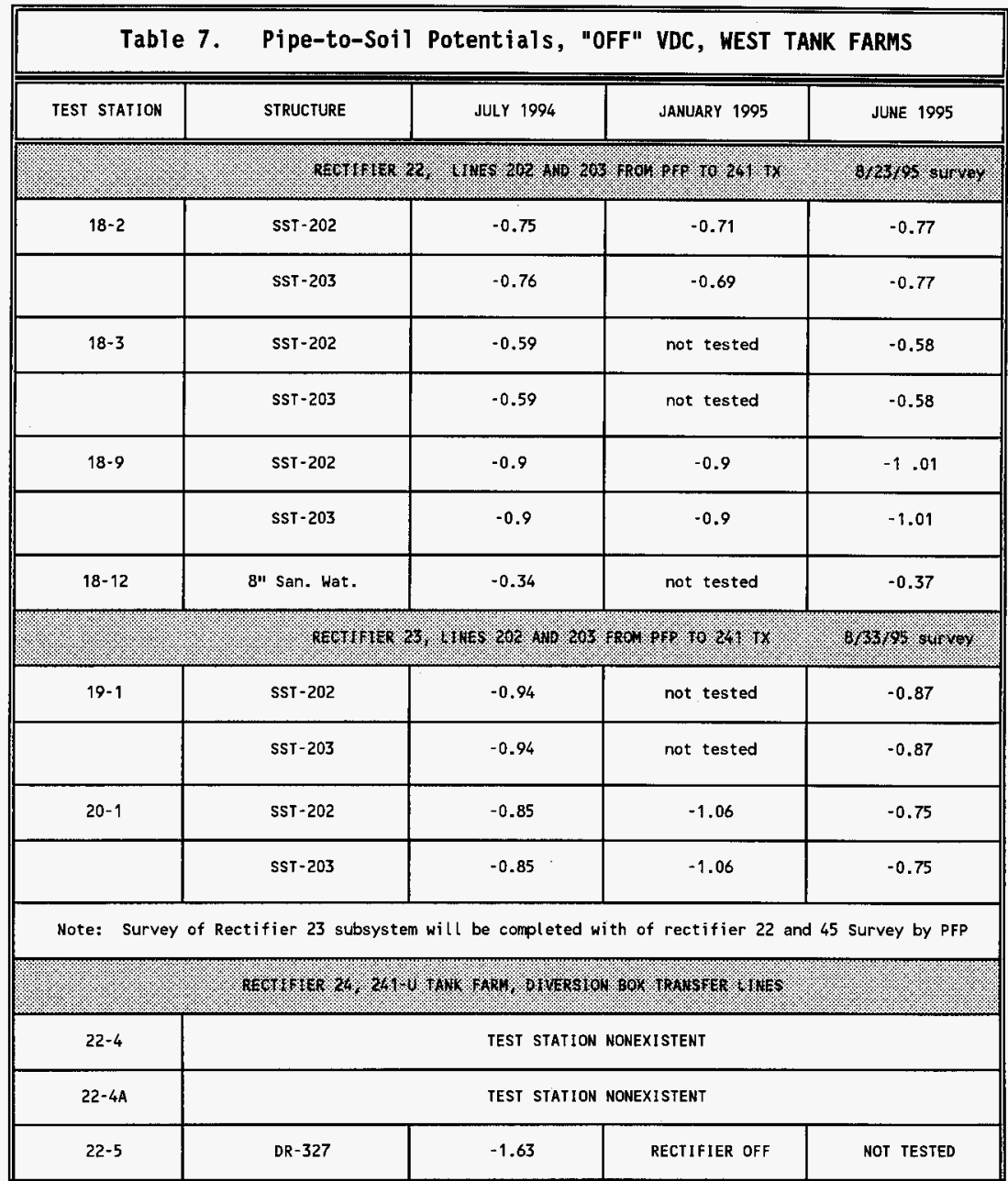


WHC-SD-WM-RPT-266, REV. 0

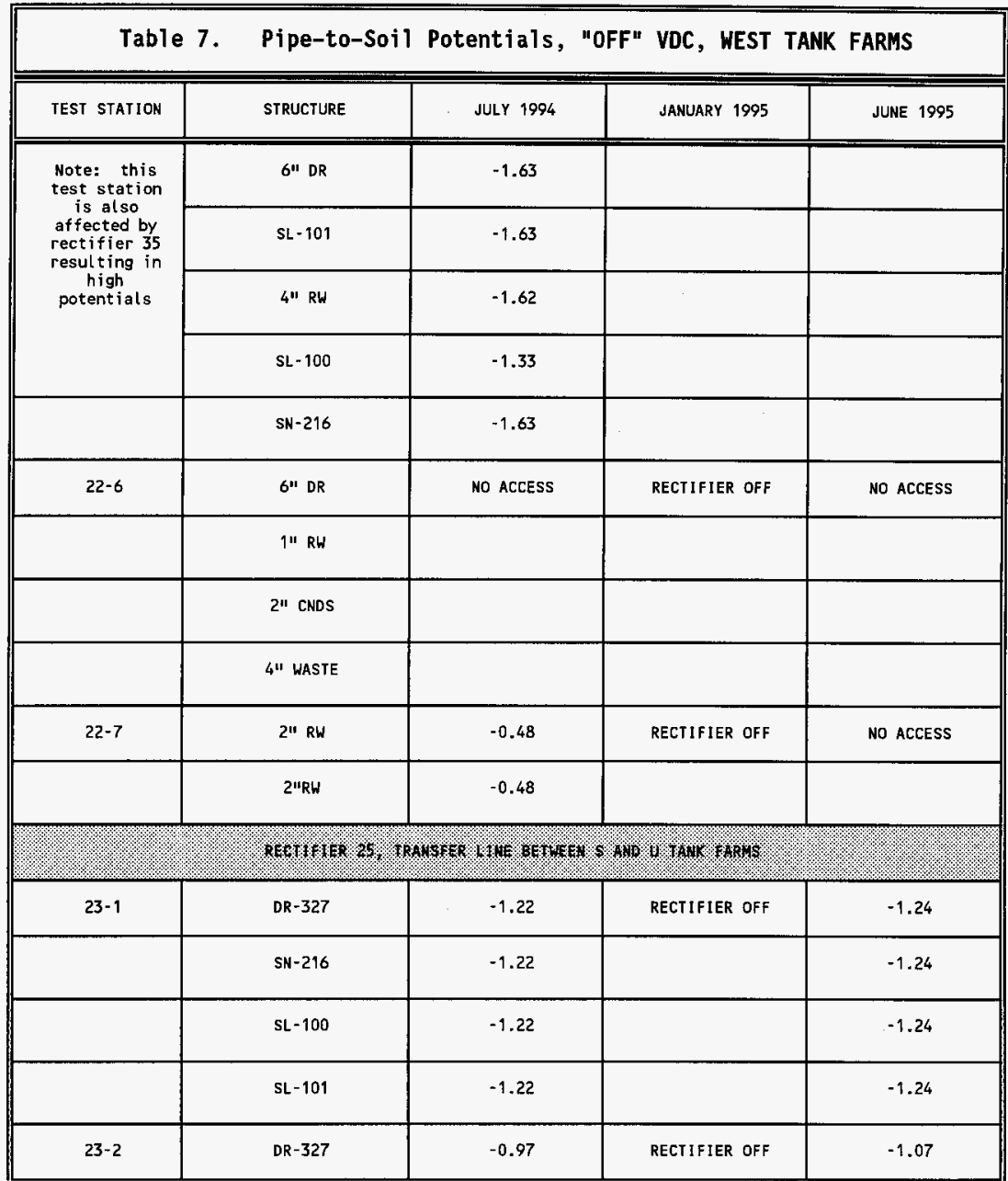


WHC-SD-WM-RPT-266, REV. 0

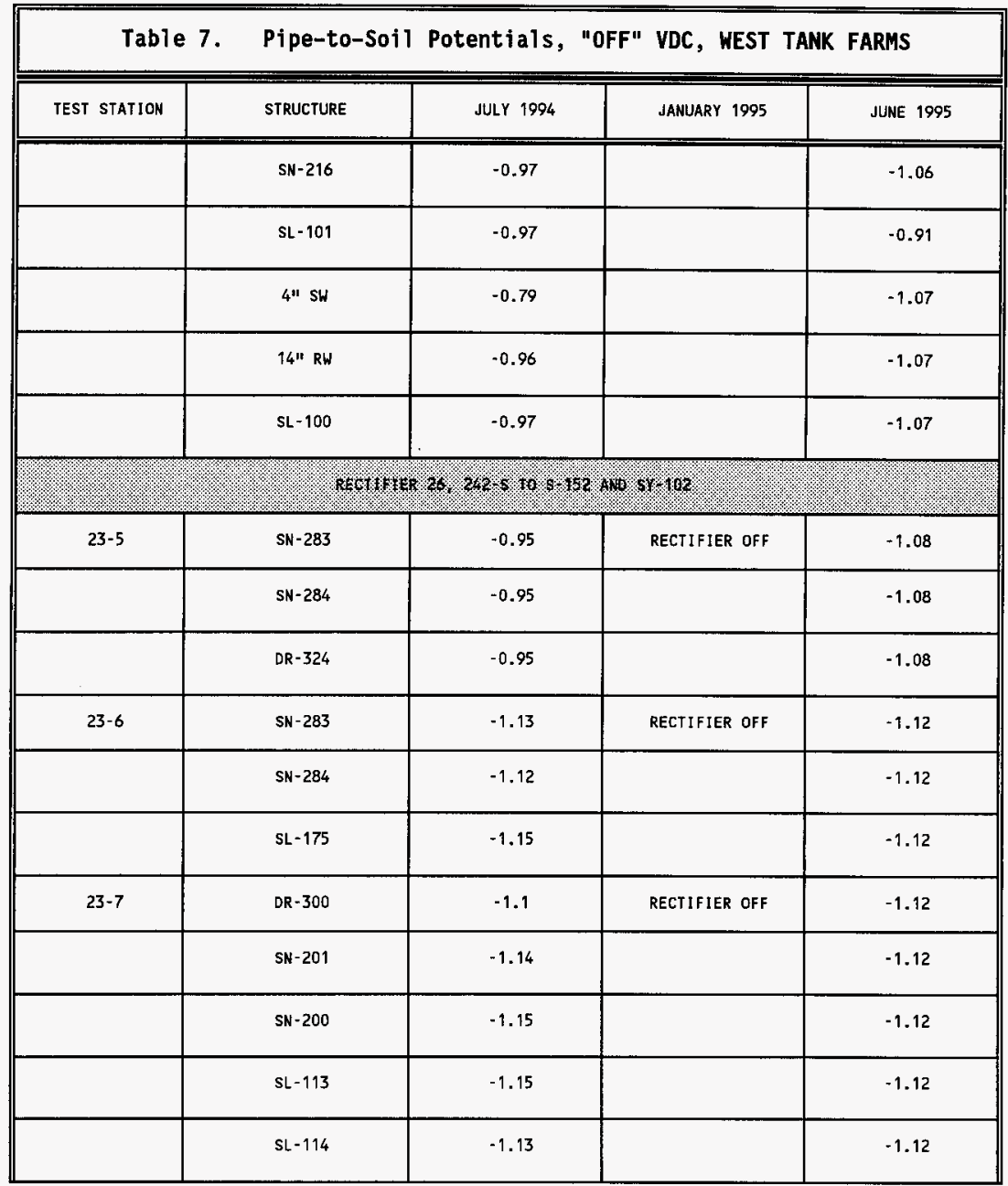


WHC-SD-WM-RPT-266, REV. 0

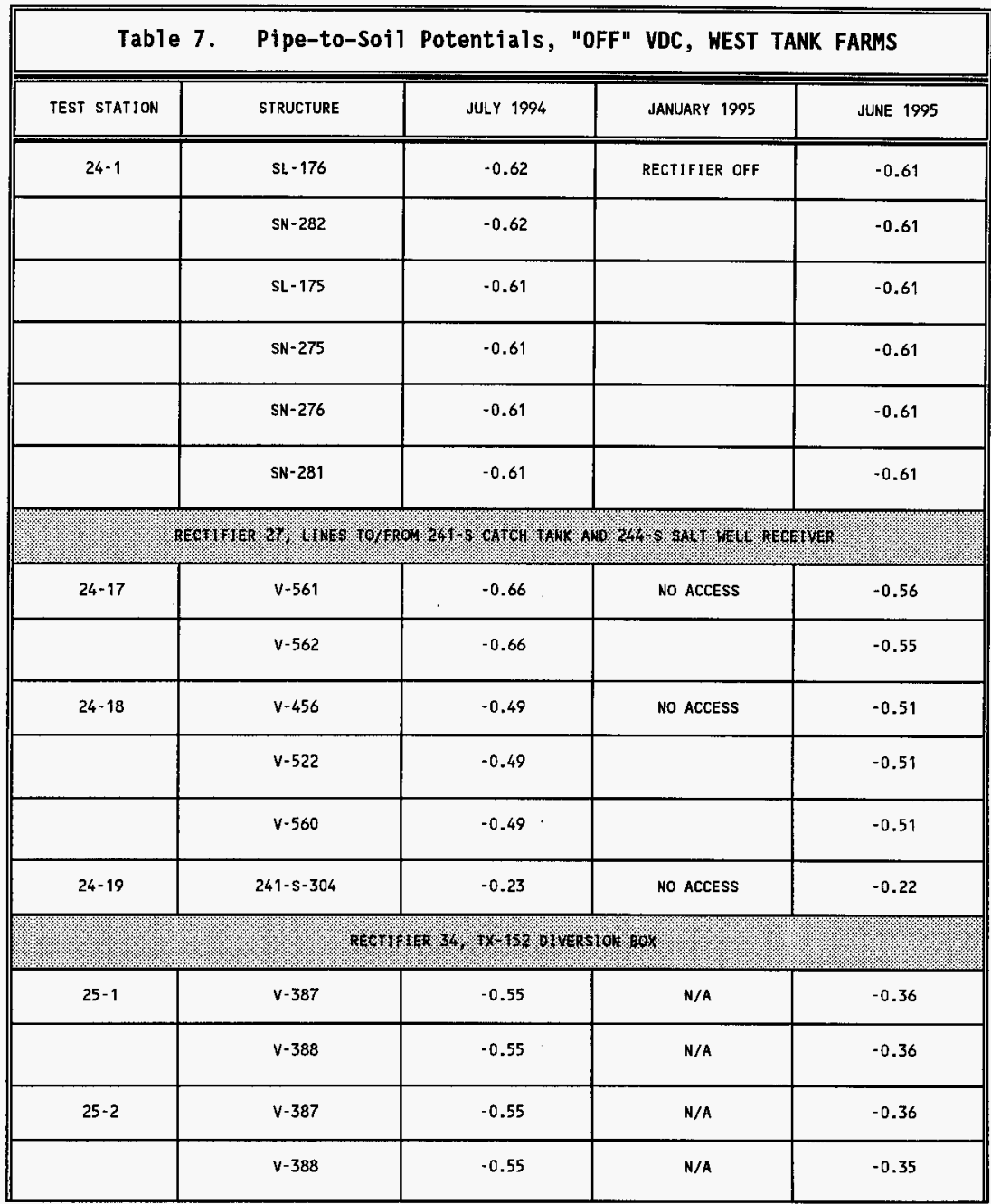


WHC-SD-WM-RPT-266, REV. 0

\begin{tabular}{|c|c|c|c|c|}
\hline Tabl & Pipe-to-Soil & Potentials, "c & OFF" VDC, WEST T & ARMS \\
\hline TEST STATION & STRUCTURE & JULY 1994 & JAMUARY 1995 & JUNE 1995 \\
\hline \multirow[t]{2}{*}{$25-3$} & $v-404$ & -0.72 & -0.73 & -0.4 \\
\hline & $v-398$ & -0.72 & -0.73 & -0.38 \\
\hline \multirow[t]{3}{*}{$25-4$} & $V-404$ & -0.72 & -0.74 & -0.36 \\
\hline & $v-398$ & -0.72 & -0.74 & -0.37 \\
\hline & 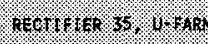 & 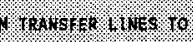 & 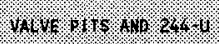 & \\
\hline $22-3$ & 6" DR & -0.77 & RECTIFIER OFF & -0.6 \\
\hline $22-10$ & $S N-216$ & -0.38 & RECTIFIER OFF & -0.37 \\
\hline \multirow[t]{3}{*}{$22-17$} & 4" WASTE & -0.69 & RECTIFIER OFF & -0.65 \\
\hline & 2" CNDS & -0.69 & & -0.65 \\
\hline & 4" RW & -0.69 & & -0.65 \\
\hline \multirow[t]{6}{*}{$22-18$} & SN-266 & -0.97 & & -0.84 \\
\hline & SN-265 & -0.97 & & -0.84 \\
\hline & SN-264 & -0.97 & & - \\
\hline & $S N-216$ & -0.97 & & -- \\
\hline & 3" SCH. 40 & -0.97 & & - \\
\hline & 4"RW & -0.89 & & $\cdots$ \\
\hline \multirow[t]{2}{*}{$22-21$} & $S L=101$ & -1.25 & RECTIFIER OFF & -1.25 \\
\hline & $S N-216$ & -1.25 & & -1.24 \\
\hline
\end{tabular}


WHC-SD-WM-RPT-266, REV. 0

\begin{tabular}{|c|c|c|c|c|}
\hline \multirow[t]{3}{*}{ TEST STATION } & STRUCTURE & JULY 1994 & JANUARY 1995 & JUNE 1995 \\
\hline & $5 N-208$ & -1.26 & & -. \\
\hline & SL- 100 & -1.24 & & -- \\
\hline \multirow[t]{6}{*}{$22-23$} & $S N-266$ & -0.45 & RECTIFIER OFF & -0.53 \\
\hline & $S N-265$ & -0.45 & & -0.53 \\
\hline & $S N-264$ & -0.45 & & -. \\
\hline & $1-1 / 2^{\prime \prime} \mathrm{FL}$ & -0.45 & & - \\
\hline & SL- 106 & -0.45 & & $-\cdot$ \\
\hline & SL- 108 & -0.45 & & $\cdots$ \\
\hline \multicolumn{5}{|c|}{ 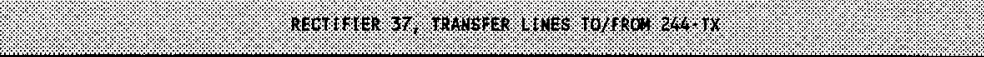 } \\
\hline \multirow[t]{5}{*}{$21-4$} & SN-211 & -0.72 & & -0.68 \\
\hline & $S N-208$ & -0.72 & & -0.68 \\
\hline & SN-204 & -0.72 & & -- \\
\hline & SN-200 & -0.72 & & -- \\
\hline & 2" PA & -0.72 & & -. \\
\hline \multirow[t]{3}{*}{$21-5$} & $\mathrm{SN}-200$ & -0.66 & & -0.55 \\
\hline & SST -203 & -0.67 & & -0.55 \\
\hline & SST - 202 & -0.66 & & -. \\
\hline
\end{tabular}


WHC-SD-WM-RPT-266, REV. 0

\begin{tabular}{|c|c|c|c|c|}
\hline \multirow[t]{4}{*}{ TEST STAIION } & STRUCTURE & JULY 1994 & JANUARY 1995 & JUNE 1995 \\
\hline & SN-204 & -0.66 & & -. \\
\hline & $S N-208$ & -0.66 & & -- \\
\hline & SN-211 & -0.66 & & -- \\
\hline \multirow[t]{4}{*}{$21-6$} & SST-203 & -0.66 & & -0.61 \\
\hline & SST-202 & -0.66 & & -0.61 \\
\hline & $611 \mathrm{RW}$ & -0.33 & & -. \\
\hline & CI WCW & -0.66 & & -. \\
\hline \multirow[t]{6}{*}{$21-7$} & $\mathrm{SN}-211$ & -0.53 & & -0.56 \\
\hline & SST-203 & -0.53 & & -0.57 \\
\hline & SST-202 & -0.53 & & .. \\
\hline & $5 N-206$ & -0.53 & & -. \\
\hline & SN-249 & -0.53 & & -. \\
\hline & SN-208 & -0.53 & & -. \\
\hline \multirow[t]{4}{*}{$21-10$} & $v-406$ & -0.73 & & -0.75 \\
\hline & $v-408$ & -0.73 & & - \\
\hline & $v-402$ & -0.73 & & -. \\
\hline & $1-1 / 2^{\prime \prime}$ DR & -0.73 & & -0.76 \\
\hline
\end{tabular}


WHC-SD-WM-RPT-266, REV. 0

\section{DISCUSSION}

Most of the CP systems were found operating as intended and only minor tap setting adjustments of some of the rectifiers were required after an evaluation of the survey data. Some rectifier adjustments were made at the time of the surveys in an effort to bring the rectifiers to the operating conditions recommended by the consultant following the 1994 basel ine survey. The survey results are described below:

\section{Rectifier 22}

This rectifier was surveyed in conjunction with the PFP survey on August 23, 1995. The test stations associated with this rectifier exist within the PFP security fence. The polarized potentials on the lines designed for protection would meet the 100 millivolt shift criteria if the native potentials were more positive than -0.48 volts at test station 18-3. Field tests of native potentials would be required. The sanitary water line at test station 18-12 is not designed for protection and the more positive potential recorded on the line indicates the line is not receiving any current. No adjustments were made to the rectifier. The rectifier is operating at the maximum tap setting and no lines are being over-protected.

\section{Rectifier 23}

The amperage output of rectifier 23 fluctuated during 1995 . The structure-to-soil potentials on SST-202 and SST-203 remained near or more negative than the -0.85 standard. No adjustments were made to the rectifier as the polarization potentials were adequate to provide corrosion protection. Part of this subsystem was surveyed with Rectifier 22 and 45 by PFP. Test station 19-1 is within the security buffer zone of PFP.

\section{Rectifier 24}

Testing this subsystem was not achieved this year due to nonexistent and/or not accessible test stations. This subsystem is in need of testing to evaluate its operation. Test stations 22-6 and 22-7 were not accessible during the survey. The test stations were under cover blocks. Test stations $22-4$ and $22-4 A$ located near the 241-U-151 and 152 Diversion Boxes were never installed. Furthermore, lines entering these diversion boxes were never bonded together and may be experiencing accelerated corrosion from stray currents. 
WHC-SD-WM-RPT-266, REV. 0

The installation of test stations $22-4$ and 22-4A and bonding the transfer lines was interrupted in 1993 due to funding. This work should be completed to properly operate the CP system for proper protection of transfer lines entering the diversion boxes.

\section{Rectifier 25}

The structure-to-soil potentials were found to be more negative than required. The rectifier output was adjusted from B-5 to B-3 to make the polarization potentials more positive.

The $4^{\prime \prime}$ SW line was found isolated and picking up stray currents. This line was bonded into the cathodic protection system to eliminate the possibility of stray current corrosion.

\section{Rectifier 26}

The structure-to-soil potentials were found adequate with the exception of the transfer lines to SY-102. Project W-430 installed cathodic protection in 241-SY Tank Farm in 01/96. The new system provides the additional current necessary for protection. Reducing the output from this rectifier was advised to make the potentials more positive. The tap settings were reduced to A-5 in 1995.

\section{Rectifier 27}

This rectifier provides partial protection of three pipes (V560, V561 and V562) which are routed from the 241-SY Tank Farm south to the 244-S Saltwell Receiver and the 241-S-151 Diversion Box. The rectifier tap settings were maximized in 1995 . The rectifier output is providing over 100 millivolts of polarization to the lines near the receiver vessel. The rectifier output voltage was lowered during the $W-430$ 0TP testing to 100 volts, and then increased to 120 volts. The 100 millivolt polarization shift was still met at the lower voltage.

The measurement taken on the 241-S-304 Catch Tank is for reference only. The tank is considered non-protected piping and almost no current is being collected at the riser of the tank.

Modifications to this subsystem would be required to elevate the potentials to the most conservative -0.85 volt criteria. This could possibly be achieved by installing more anodes near the pipes. The rectifier is rated at 18 amps and was only delivering 3 amps during the annual test.

Test stations should be installed on $V-561$ and -562 between 241-S salt well receiver and SY tank farm to allow for further potential characterizations. 
WHC-SD-WM-RPT-266, REV. 0

\section{Rectifier 34}

This subsystem was determined to be operating with low current output during the survey. The tap settings-were increased to B-5 after measuring the pipe-to-soil potentials. The transfer lines require native potential measurements to gauge the 100 millivolt shift criteria.

\section{Rectifier 35}

The tap settings of this rectifier were increased from the initial June 1994 settings. The output current and structure-to-soil potential decreased from the June 1994 survey. Rectifier adjustments were recommended to drive the potentials in the more negative direction. Tap settings were changed to $\mathrm{B}-3$.

\section{Rectifier 37}

A11 the measured structure-to-soil potentials on the transfer system protected by this rectifier were found more positive than the -0.85 volt criteria. The rectifier was adjusted to the tap setting of B-2 at the time of the survey in an effort to make the potentials more negative.

Two cases of discontinuity were located during the surveys in West Tank Farm. The two lines were picking up stray current. The isolated structures were bonded to the system by joining one of the two test leads from the isolated structure to a test lead of a protected structure. Both test leads were located in the same test stations. The isolated lines bonded to the $C P$ systems were as follows:

* RW in 241-U Tank Farm at test station 22-31

* $\quad 4^{\prime \prime}$ SW north of 242-S Evaporator at test station 23-2

\subsection{PFP Facilities}

The Plutonium Finishing Plant's (PFP) cathodic protection (CP) system associated with Rectifier 45 was surveyed per Engineering Task Plan, Engineering Task Plan, PFP Cathodic Protection System Maintenance (WHC-SD-WMETP-147). The PFP annual survey required coordination with Tank Farm Maintenance and 0perations to install pulse generators on Rectifier 22 , which is located just outside the security fence, and on Rectifiers 23 and 37 , which are located near 241-TX Farm. These rectifier systems, along with Rectifier 45 , may influence each other $s$ operation inadvertently due to stray currents and influence the results of the survey. 
The CP system provides corrosion protection, as required by WAC 173-303-640, to PFP's underground transfer lines which are located between the $241-Z$ and $236-2$ buildings. The protected Tines are:

2" LSW-M9 W/4" ENC-M9,

2" SPARE-M9 $w / 4^{\prime \prime}$ ENC-M9,

2" HSW-M9 W/4" ENC-M9, and

2" SPARE-Mg W/4" ENC-M9.

Other lines in the vicinity may or may not be intentionally protected by the $\mathrm{CP}$ system. These lines, where they exist, were also tested during the survey.

The WAC Code requires annual surveys to assure the underground piping are adequately protected. Besides the annual surveys, bimonthly (every other month) rectifier inspections are required to verify the system is energized and operating. According to the Engineering Task $\mathrm{Pl}$ an, bimonthly rectifier inspections are performed and documented by PFP. With PFP maintenance support, the 1995 annual $C P$ survey was performed and the acquired data evaluated. These tests were performed on August 23, 1995 by PFP Electrical Maintenance with support of TWRS M\&CE.

A permanent pulse generator exists in series with rectifier 45 to cycle the rectifier output on and off. Pulse generators were installed on Tank Farm's Rectifier 22, 23, and 37 . These rectifiers protect the transfer 1ines which traverse from PFP to the 244-TX Salt Well Receiver.

\section{SURVEY RESULTS}

Rectifier 45, a standard oil-filled rectifier operating at constant voltage, was visually inspected and found in good condition. The rectifier oil appeared clean, in good condition, and at the proper level. No oil leaks from the rectifier were found. The rectifier gasket was replaced due to tearing. The permanently installed pulse generator was not operating properly. The 
rectifier output did not pulse as designed. The pulse generator was found incorrectly wired to the rectifier. The PFP Electrical Maintenance corrected the wiring and the rectifier/pulse generator series circuit operated as designed. The operational characteristics of Rectifier 45 are provided below:

\section{Rectifier 45}

Make: Good-A11 Electric

Model: CSOYSA 50-12 GLMTZ

Serial \#: $92 \mathrm{C} 1418$

Part \#: 0084706

Rectifier Input: 120 volts (AC), 7.5 amps

Maximum Rectifier output: 50 volts (DC), 12 amps

Taps (as found): $\mathrm{C}-1$

Rectifier Output:

DC amps (as found):

$\begin{array}{cc}\text { Pane } 1 \text { Readings } & \text { Meter (Portable) Readings } \\ 30 \mathrm{VDC} & 5.39 \mathrm{VDC} \\ 5.25 \mathrm{amps} & 5.31 \mathrm{amps}\end{array}$

Shunt: 15 amps 50 mVolts

The survey results are presented in Table 8 . The tap settings were set at C-1. As required by Tank Farm Maintenance test procedure 6-TF-357, Rev. 0, Testing of Cathodic Protection System, continuity tests were performed between each pipe in each test station. At test stations 45-1, 45-2, and 45-3 the resistance between test leads was greater than the $10 \mathrm{ohm}$ criteria. This showed that adequate continuity between the pipes does not exist as designed. This suggests that the jumper cables may not have been installed on the piping near the 241-Z Building (H-2-87513, Rev. 1). Continuity exists at the remaining test stations.

Polarization potentials measured at test stations 45-1, 45-2, and 45-3 did not meet the -0.85 voltage criteria. "ON" minus "OFF" potential differences showed no current being collected by the pipes at stations 45-1 and 45-2 and that a relatively small amount of current was collected by the pipes at 45-3. This showed that cathodic protection between $241-Z$ and $243-Z$ Building, near anode jumper box AJB R45-1, was not being provided. The anode header cable had been disconnected at the rectifier and the anode junction box (AJB R45-1). The header cable was disconnected because field tests had shown that the header cable, shorting out in this region, caused the rectifier to continually overload its circuit.

Adequate corrosion protection is provided at test stations 45-4 and 45-5. A11 other test stations exhibit potentials less than the -0.85 volt criteria. Test station 45-7 was found flooded and the piping test leads were moderately corroded. 
To overcome the lack of continuity near $241-z$ building, the buried piping may be bonded together by either of two methods. The piping may be excavated to attach jumpers. A second less costly method would be to bond the lines together attaching jumpers between the test leads within the test box. If excavation of the CP system is $\mathrm{planned}$ to troubleshoot and repair the shorting anode header cable between $241-Z$ and $243-Z$ buildings, the lines could be easily bonded together.

Increasing the rectifier output is required to increase the polarized potentials at test stations $45-6,-7$, and -8 . The rectifier tap settings were changed to $\mathrm{C}-4$ to increase the rectifier output. Once the disconnected header cable is reinstalled, the $C P$ system must be surveyed again to assure the additional load does not reduce the protective current on the part of the system that is currently operating.

Test station 45-7 should be drained of water and the test leads cleaned of corrosion product. The cause of flooding in test station 45-7 should be identified and mitigated. The test station should be monitored to assure flooding does not occur again.

\begin{tabular}{|c|c|c|c|c|c|c|c|}
\hline & Table & Pip & o-Soi & tenti & (VDC & FP & \\
\hline \multirow{2}{*}{$\begin{array}{c}\text { Test } \\
\text { Station }\end{array}$} & \multirow{2}{*}{$\begin{array}{c}\text { Buried } \\
\text { Structure }\end{array}$} & \multicolumn{2}{|c|}{ Portable Ref. } & \multicolumn{2}{|c|}{ Ref. Cell 1} & \multicolumn{2}{|c|}{ Ref. Cell 2} \\
\hline & & on & off & on & Off & On & off \\
\hline \multirow[t]{4}{*}{$45-1$} & 2" LSW & -0.420 & -0.416 & -0.435 & -0.436 & N/A & N/A \\
\hline & LSW Spare & -0.421 & -0.421 & -0.437 & -0.434 & N/A & N/A \\
\hline & 2" HSW & -0.423 & -0.420 & N/A & N/A & $N / A$ & N/A \\
\hline & HSW Spare & -0.425 & -0.426 & $\mathrm{~N} / \mathrm{A}$ & N/A & N/A & N/A \\
\hline \multirow[t]{6}{*}{$45-2$} & 2" LSW & -0.424 & -0.420 & -0.386 & -0.387 & -0.328 & -0.331 \\
\hline & LSW Spare & -0.427 & -0.427 & -0.389 & -0.388 & -0.332 & -0.332 \\
\hline & Unknown 1 & -0.408 & -0.405 & N/A & $N / A$ & N/A & H/A \\
\hline & Unknown 2 & -0.411 & -0.410 & N/A & N/A & $N / A$ & $N / A$ \\
\hline & 2" HSW & -0.423 & -0.424 & $N / A$ & N/A & N/A & N/A \\
\hline & HSW Spare & -0.423 & -0.423 & N/A & N/A & $N / A$ & N/A \\
\hline \multirow[t]{2}{*}{$45-3$} & $2^{\prime \prime} \mathrm{LSW}$ & -0.385 & -0.349 & -0.522 & -0.464 & 0.431 & -0.396 \\
\hline & LSW Spare & -0.383 & -0.348 & -0.522 & -0.460 & -0.432 & -0.400 \\
\hline
\end{tabular}


WHC-SD-WM-RPT-266, REV. 0

\begin{tabular}{|c|c|c|c|c|c|c|c|}
\hline & Table & Pip & to-Soil & otenti & (VDC), & $F P$ & \\
\hline \multirow{6}{*}{$\begin{array}{c}\text { Test } \\
\text { Station }\end{array}$} & \multirow{2}{*}{$\begin{array}{l}\text { Buried } \\
\text { structure }\end{array}$} & \multicolumn{2}{|c|}{ Portable Ref. } & \multicolumn{2}{|c|}{ Ref. Cell 1} & \multicolumn{2}{|c|}{ Ref. Cell 2} \\
\hline & & On & off & On & off & On & off \\
\hline & 2" HSH & -0.385 & -0.347 & N/A & $\mathrm{N} / \mathrm{A}$ & $N / A$ & $N / A$ \\
\hline & HSW Spare & -0.385 & -0.349 & $N / A$ & $N / A$ & $N / A$ & H/A \\
\hline & Unknown 1 & $N / A$ & -0.319 & $N / A$ & $N / A$ & $N / A$ & $N / A$ \\
\hline & Unknown 2 & -0.370 & -0.348 & $N / A$ & W/A & N/A & $N / A$ \\
\hline \multirow[t]{2}{*}{$45-4$} & 2" LSW & -2.437 & -0.860 & -1.250 & -0.970 & -1.492 & -0.968 \\
\hline & LSW spare & -2.436 & -0.860 & -1.250 & -0.970 & -1.490 & -0.968 \\
\hline \multirow[t]{2}{*}{$45-5$} & $2 " L 5 W$ & -1.306 & -0.870 & -0.600 & -0.555 & N/A & N/A \\
\hline & LSW Spare & -1.306 & -0.872 & -0.600 & -0.556 & H/A & N/A \\
\hline \multirow[t]{2}{*}{$45-6$} & 2" LSW & -0.790 & -0.609 & -0.493 & -0.455 & -0.456 & -0.427 \\
\hline & LSW Spare & -0.789 & -0.606 & -0.493 & -0.454 & -0.456 & -0.432 \\
\hline \multirow[t]{2}{*}{$45-7$} & 2" LSW & -1.659 & -0.801 & -3.141 & -0.660 & -1.337 & -0.708 \\
\hline & LSW Spare & -1.659 & -0.798 & -3.140 & -0.667 & -1.337 & -0.705 \\
\hline \multirow[t]{2}{*}{$48-8$} & 2" LSW & -0.712 & -0.588 & -0.724 & -0.613 & -0.592 & -0.532 \\
\hline & LSW Spare & -0.711 & -0.590 & -0.723 & -0.615 & -0.591 & -0.530 \\
\hline
\end{tabular}

\section{$2.6 \quad 222-5$ Laboratory}

Cathodic protection was installed in 1995 under project $W-041 \mathrm{H}$, Environmental Hot Cell Expansion, and energized by ICF-Kaiser Engineers. As detailed in Drawing $\mathrm{H}-2-83281$, Rev. 1 , this $\mathrm{CP}$ system provides corrosion protection to underground transfer lines between the 222-S Bldg expansion and Tank 101. The protected lines are:

2" DR-1-M9 W/4" Enc-M9,

2" DR-2-M9 w/4" Enc-M9, and

all stainless steel HVAC piping in contact with earth. 
WHC-SD-WM-RPT-266, REV. 0

This cathodic protection system consists of Rectifier R-44 and two test stations $(T(44-4)$ and $T(44-4 A))$. These test stations are located in a single test enclosure behind 222-S Bldg Expansion. Fifteen vertical anodes are installed in series via the anode loop cable to direct the protective currents onto the above referenced protected lines.

A second cathodic protection system was installed in 1996 to protect the new 1 iquid waste drain 1 ines from 222-S Laboratory to 219-S Building (Tank 101). This system was installed under Hanford Project W-087, Radioactive Liquid Waste Line Replacement. This system has been energized since 5/28/96 following the successful completion of the Acceptance Test Procedure W-087ATP-001 Rev. 2. The lines under protection are:

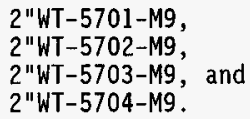

Following completion of Project $W-041 \mathrm{H}$, the $C P$ system was surveyed per WAC 173-303-640 on Apri1 7, 1995. Tests performed showed the cathodic protection system was operating at a pipe-to-soil potential $<(-) 1 \mathrm{~V}$ versus a copper/copper sulfate reference electrode. The pipe-to-soil potential measurements were not made with the use of a pulse generator/waveform analyzer combination. Hence the resulting readings were not polarized potential readings and represented an additional IR voltage drop in the potential readings.

Following these preliminary tests, the rectifier was inspected and the CP system was surveyed on June 14, 1995 with the use of a pulse generator/waveform analyzer combination.

\section{SURVEY RESULTS}

The Rectifier 44 CP system was surveyed at Test Stations 44-4 and 44-4A. The other test stations depicted on Drawing H-2-83281, Rev. I (Test Stations 44-1 through 44-3) were not installed. The Anode Junction Box AJB 44-1 was located within the RCA zone near Tank 101 under the protective tarpaulin/berm. The tarpaulin is used for 1iquid containment during (storage tank)-to-(tank car) pumping operations.

Rectifier 44 was found operating and in good condition. The rectifier design is similar to all others at Hanford. The rectifier is an oil-cooled unit operating at constant voltage. The transformer oil appeared clean, in good condition, and at the proper level. Very small oil weeps were observed from welds near one bottom corner of the rectifier case.

The as-found characteristics of rectifier 44 are provided below: 
WHC-SD-WM-RPT-266, REV. 0

\section{Rectifier 44}

Make: Good All Electric

Model: CSOYSA 60-12 GNTZ

Serial \#: $92 \mathrm{C} 1881$

Part \#: 0085167

AC Input: 120 volts

AC Current: 8.9 amps

Maximum Output: 60 volts (DC), 12 amps

Taps (as found): B-5

$D C$ Potential (as found)

DC Amps (as found):

\section{Panel Readings}

34

2.75
Meter (Portable) Readings

33.4

3

Shunt: 15 amps $50 \mathrm{mVolts}$

Pipe-to-soil potentials measured with the portable reference cell are used rather than those obtained with the permanent reference cell(s). The potentials obtained with the permanent reference cells are questionable. The difference in potentials between the portable and permanent reference cells was possibly due to the permanent reference cells located under the laboratory facility and/or the drier soil. Past experience indicates that data obtained with the permanent reference cells are questionable. This is clearly evident in the results presented in Table 9.

The initial pipe-to-soil potential measurements with the rectifier tap settings at B-5 are presented in Table 9 . Not only are differences observed between the portable and permanent reference cells, but differences exist between the measured potentials of both permanent reference cells in Test Station 44-4. 
WHC-SD-WM-RPT-266, REV. 0

\begin{tabular}{|c|c|c|c|c|c|c|c|}
\hline \multirow{2}{*}{$\begin{array}{c}\text { Test } \\
\text { station }\end{array}$} & \multirow{2}{*}{$\begin{array}{l}\text { Buried } \\
\text { structure }\end{array}$} & \multicolumn{2}{|c|}{ Portable Reference } & \multicolumn{2}{|c|}{ Reference Cell 1} & \multicolumn{2}{|c|}{ Reference Cell 2} \\
\hline & & ON & OFF & ON & OFF & $\mathrm{ON}$ & OFF \\
\hline \multirow[t]{4}{*}{$44-4$} & $16 "$ duct north (1) & -2.652 & -1.272 & -1.038 & -0.644 & -1.578 & -0.475 \\
\hline & $16^{\prime \prime}$ duct south (1) & -2.651 & -1.271 & -1.038 & -0.646 & -1.578 & -0.476 \\
\hline & 16" duct south (2) & -2.652 & -1.271 & -1.038 & -0.643 & -1.578 & -0.478 \\
\hline & $16^{\prime \prime}$ duct north (2) & -2.653 & -1.276 & -1.038 & -0.644 & -1.577 & -0.475 \\
\hline \multirow[t]{4}{*}{$44-4 \mathrm{~A}$} & DR-1 (1) & -2.621 & -1.252 & -0.510 & -0.371 & -- & $\cdots$ \\
\hline & $D R-2(1)$ & -2.621 & -1.255 & -0.509 & -0.374 & -- & - \\
\hline & $D R-2(2)$ & -2.620 & -1.254 & -0.510 & -0.374 & - & -- \\
\hline & $D R-1(2)$ & -2.620 & -1.254 & -0.510 & -0.374 & $-\cdot$ & - \\
\hline
\end{tabular}

The "OFF" potentials measured using the portable reference cell were found to be greater (electronegatively) than the -0.85 volt criteria. The tap settings were reduced from B-5 to B-3 to bring the "OFF" potentials in line with the criteria. The structures were retested after adequate time allowing for system stabilization. The pipe-to-soil potential measurements at this reduced tap setting are presented in Table 10 . The potentials measured utilizing the permanent reference cells were not obtained.

Table 10. Pipe-to-Soil Potentials (VDC), 222-S at Tap Setting B-3

\begin{tabular}{|c|c|c|c|c|c|c|c|}
\hline \multirow{2}{*}{$\begin{array}{c}\text { Test } \\
\text { Station }\end{array}$} & \multirow{2}{*}{$\begin{array}{l}\text { Buried } \\
\text { structure }\end{array}$} & \multicolumn{2}{|c|}{ Portable Reference } & \multicolumn{2}{|c|}{ Reference Cell 1} & \multicolumn{2}{|c|}{ Reference Cell 2} \\
\hline & & ON & OFF & ON & OFF & ON & OFF \\
\hline \multirow[t]{4}{*}{$44-4$} & 16" duct north (1) & -2.242 & -1.195 & - & -- & -- & - \\
\hline & $16^{\prime \prime}$ duct south (1) & -2.241 & -1.195 & $\cdots$ & $\cdots$ & -- & -- \\
\hline & 16" duct south (2) & -2.242 & -1.195 & -- & - & - & -- \\
\hline & 16" duct north (2) & -2.243 & -1.196 & -. & - & -. & $\ldots$ \\
\hline
\end{tabular}


WHC-SD-WM-RPT-266, REV. 0

\begin{tabular}{|c|c|c|c|c|c|c|c|}
\hline \multirow{2}{*}{$\begin{array}{c}\text { Test } \\
\text { Station }\end{array}$} & \multirow{2}{*}{$\begin{array}{l}\text { Buried } \\
\text { Structure }\end{array}$} & \multicolumn{2}{|c|}{ Portable Reference } & \multicolumn{2}{|c|}{ Reference Cell 1} & \multicolumn{2}{|c|}{ Reference Cell 2} \\
\hline & & ON & off & ON & OFF & ON & OFF \\
\hline \multirow[t]{4}{*}{$44-4 A$} & $D R-1(1)$ & -2.252 & -1.205 & -- & -- & -- & -- \\
\hline & $D R-2(1)$ & -2.252 & -1.202 & -. & -- & -. & -. \\
\hline & $D R-2(2)$ & -2.252 & -1.200 & -. & -. & -- & -. \\
\hline & $D R-1 \quad(2)$ & -2.251 & -1.203 & -- & .. & .. & .. \\
\hline
\end{tabular}

As the resulting pipe-to-soil potential measurements continued to remain more negative than the -0.85 volt criteria, the tap settings were lowered to $\mathrm{A}-2$ and the system allowed to stabilize. The rectifier output characteristics at tap setting A-2 were 0.625 Amps at 5 volts. The pipe-to-soil potential measurements are presented in Table 11. The potentials were found to be more positive than the NACE criteria, requiring an increase in the rectifier output.

\begin{tabular}{|c|c|c|c|c|c|c|c|}
\hline \multicolumn{8}{|c|}{ Table 11.} \\
\hline \multirow{2}{*}{$\begin{array}{c}\text { Test } \\
\text { Station }\end{array}$} & \multirow{2}{*}{$\begin{array}{l}\text { Buried } \\
\text { structure }\end{array}$} & \multicolumn{2}{|c|}{ Portable Reference } & \multicolumn{2}{|c|}{ Reference Cell 1} & \multicolumn{2}{|c|}{ Reference Cel! 2} \\
\hline & & ON & OFF & ON & OFF & ON & OFF \\
\hline \multirow[t]{4}{*}{$44-4$} & $16 "$ duct north (1) & -0.980 & -0.679 & -- & $\cdots$ & - & - \\
\hline & $16^{\prime \prime}$ duct south $(1)$ & -0.980 & -0.677 &.- & $\cdots$ & $\cdots$ & - \\
\hline & $16^{11}$ duct south (2) & -0.980 & -0.677 & - & -- & - & -- \\
\hline & $16 "$ duct north (2) & -0.979 & -0.675 & -- & $\cdots$ & - & - \\
\hline \multirow[t]{4}{*}{$44-4 A$} & $D R-1(1)$ & -0.992 & -0.686 & $\cdots$ & $-\cdot$ & $\cdots$ & - \\
\hline & $D R-2(1)$ & -0.992 & -0.684 & - & -- & - & - \\
\hline & $D R-2(2)$ & -0.992 & -0.682 & $-\cdot$ & - & - & -- \\
\hline & $D R-1(2)$ & -0.992 & -0.686 & - & $\ldots$ & -- & -. \\
\hline
\end{tabular}


WHC-SD-WM-RPT-266, REV. 0

Assuming an approximate linear relationship between the rectifier output and the pipe-to-soil "OFF" potentials at tap settings B-5 and A-2, a rectifier output of 14 volts was recommended. The tap settings were increased to A-4. The initial rectifier output at tap setting A-4 was 1.5 amps. The cathodic protection system was allowed to stabilize and was resurveyed at a later date.

The pulse generator was removed and the rectifier returned to normal operation. The system was allowed to stabilize for a few months and then reevaluated. On November 9, 1995 the pulse generator was reinstalled and the system retested during the bi-monthly inspection of the cathodic protection Rectifier 44.

The steady state rectifier tap setting (A-4) provided an electrical output of $12.8 \mathrm{Vdc}$ at 0.99 amps. As anticipated, the output current decreased from the initial output of $1.5 \mathrm{amp}$. This decrease in current is due to polarization of impressed current anodes over time. The pipe-to-soil potentials were measured with a wave form analyzer, capturing the "ON" and the "OFF" potentials generated by the pulse generator/rectifier series combination. The measured values are presented in the Table 12.

\begin{tabular}{|c|c|c|c|}
\hline \multicolumn{4}{|c|}{$\begin{array}{l}\text { Table 12. Pipe-to-Soil Potentials } \\
\text { 222-S at Tap Setting A-4 }\end{array}$} \\
\hline \multirow{2}{*}{$\begin{array}{l}\text { Test } \\
\text { station }\end{array}$} & \multirow{2}{*}{$\begin{array}{l}\text { Buried } \\
\text { structure }\end{array}$} & \multicolumn{2}{|c|}{ Portable Reference } \\
\hline & & ON & OFF \\
\hline \multirow[t]{6}{*}{$44-4$} & $16^{\prime \prime}$ duct north (1) & -1.329 & -0.845 \\
\hline & $16^{\prime \prime}$ duct south (1) & -1.330 & -0.845 \\
\hline & $16^{\prime \prime}$ duct south (2) & -1.332 & -0.845 \\
\hline & 16 "1 duct north (2) & -1.332 & -0.847 \\
\hline & Reference Horth , & 0.727 & 0.389 \\
\hline & Reference South & 0.570 & 0.511 \\
\hline \multirow[t]{5}{*}{$44-4 \mathrm{~A}$} & $D R-1$ (1) & -1.281 & -0.810 \\
\hline & $\mathrm{DR}-2$ (1) & -1.281 & -0.810 \\
\hline & $D R-2(2)$ & -1.282 & -0.812 \\
\hline & $D R-1(2)$ & -1.282 & -0.811 \\
\hline & Reference & 0.965 & 0.548 \\
\hline
\end{tabular}


WHC-SD-WM-RPT-266, REV. 0

The rectifier taps were subsequently adjusted to B-1 to increase the rectifier output. The rectifier was allowed to stabilize. On $12 / 12 / 95$, the rectifier output was measured and found to be $19.92 \mathrm{Vdc}$ at 1.62 amps. From the data obtained during the annual survey of Table 12, the rectifier will provide adequate corrosion protection. Using the previous linear correlation, the predicted pipe-to-soil "OFF" potentials will be more negative than -0.85 VDC when the rectifier output is at 19 volts.

\subsection{ON-GOING DEVELOPMENT WORK AND TESTING REQUIREMENTS}

1) Cathodic protection surveys are required on an annual basis per WAC-173303-640. In addition, bi-monthly rectifier checks are required per the WAC codes. These required activities are incorporated into the maintenance production control process. A systematic mechanism to provide these data sheets to the cathodic protection cognizant engineering position in a timely manner is under development.

2) A thorough understanding of each metal structure in contact with the ground is necessary to properly evaluate the results of the CP surveys. The results have demonstrated more positive potentials than the most conservative criteria $(-0.85 \mathrm{v})$ on many of the lines. The possible cause of these more positive potentials may be due to any of the following.

- Proximity to other transfer lines

- Proximity to waste tanks or other large metallic structures.

- Inadequate anode distribution.

- Low rectifier output.

3) To properly adjust, operate, and maintain the CP systems a thorough understanding of the system design in each tank farm along with an understanding of the buried structure configuration is required. Clear comprehensive drawings are required of each tank farm to accurately depict the installed CP system relative to the buried metallic structures, i.e., waste tanks, valve pits, other transfer lines, water lines, steam lines, etc. A CP system database that is currently under development will greatly facilitate the trouble shooting, adjustments, and modification of the $C P$ systems.

4) Native potentials must be collected at the test stations which have pipes that are not polarizing more negatively than -0.85 VDC. Generally, the high majority of native potentials are more positive than -0.5 VDC and the 100 millivolt shift criteria would be realized at a polarized potential of -0.6 VDC. 
5) Additional testing is required to see the extent of anodic polarization of the impressed current anodes. This data will provide valuable operational criteria for each CP system.

6) Baseline rectifier efficiency data should be collected to trend the operation of each rectifier.

\subsection{REFERENCES}

Jaske, R. T., HW-33504, 1954, Cathodic Protection of Stainless Steel Waste Lines, Interim Report No. 1, Underground Pipeline and Structure Corrosion Study Program.

Payer, L. H. 1980, Evaluation of Risk Assessment Document of Restarting the 242-S Evaporator, Battelle Columbus Laboratories, Columbus, Ohio.

Haberman, J. H., 1995a, Corrosion Control of Hanford Site Waste Transfer System, NACE Corrosion/95 Paper 439, National Association of Corrosion Engineers, Houston, Texas.

Haberman, J. H., 1995b, TWRS Cathodic Protection Description and Upgrade Recommendations, WHC Internal Memo \# 74A00-95-PCO-012, Westinghouse Hanford Company, Richland, Washington.

Haberman, J. H., 1995c, 1995 Annual Survey West Tank Farm Cathodic Protection System, WHC-SD-WM-ER-487, Rev. 0, Westinghouse Hanford Company, Richland, Washington.

NACE, 1992, Control of External Corrosion on Underground or Submerged Metallic Piping Systems, RPO169-92, National Association of Corrosion Engineers, Houston, Texas.

NACE, 1995, Corrosion Control of Underground Storage Tank Systems by Cathodic Protection, RP0285-95, National Association of Corrosion Engineers, Houston, Texas. 


\section{DISTRIBUTION SHEET}

\begin{tabular}{|c|c|c|c|c|c|c|}
\hline \multirow{2}{*}{$\begin{array}{l}\text { To } \\
\text { TWRS Materials \& Corrosion }\end{array}$} & \multirow{2}{*}{\multicolumn{4}{|c|}{$\begin{array}{l}\text { From } \\
\text { TWRS Ma }\end{array}$}} & \multicolumn{2}{|l|}{ Page 1 of 2} \\
\hline & & & & & \multicolumn{2}{|c|}{ Date $9 / 18 / 96$} \\
\hline \multicolumn{5}{|l|}{ Project Title/Work Order } & \multicolumn{2}{|c|}{ EDT No. 615262} \\
\hline $\begin{array}{l}1995 \text { Annual Cathodic Protection } \\
200 \text { Area }\end{array}$ & Survey & Report & \multicolumn{2}{|c|}{ or the Hanford } & \multicolumn{2}{|l|}{ ECN No. } \\
\hline Name & & MSIN & $\begin{array}{l}\text { Text } \\
\text { With All } \\
\text { Attach. }\end{array}$ & Text Only & $\begin{array}{l}\text { Attach./ } \\
\text { Appendix } \\
\text { Only }\end{array}$ & $\begin{array}{l}\text { EDT/ECN } \\
\text { Only }\end{array}$ \\
\hline $\begin{array}{l}\text { D. Al ison } \\
\text { J. J. Badden } \\
\text { T. W. Bohan } \\
\text { T. J. Bowman (5) } \\
\text { J. E. Bramson } \\
\text { K. A. Elsethagen } \\
\text { D. E. Nelson } \\
\text { P. C. Ohl } \\
\text { J. L. Pennock } \\
\text { C. C. Scaief }\end{array}$ & & $\begin{array}{l}\text { R1-51 } \\
\text { T4-07 } \\
\text { S5-04 } \\
\text { Rl-30 } \\
\text { T5-54 } \\
\text { R1-51 } \\
\text { S5-66 } \\
\text { R1-30 } \\
\text { S4-70 } \\
\text { R1-56 }\end{array}$ & $\begin{array}{l}x \\
x \\
x \\
x \\
x \\
x \\
x \\
x \\
x \\
x\end{array}$ & & & \\
\hline Central Files (Orig. +3 copies) & & A3-88 & $x$ & & & \\
\hline
\end{tabular}




\section{DISTRIBUTION SHEET}

\begin{tabular}{|c|c|c|c|c|c|}
\hline \multirow{2}{*}{$\begin{array}{l}\text { To } \\
\text { TWRS Materials \& Corrosion }\end{array}$} & \multirow{2}{*}{\multicolumn{3}{|c|}{$\begin{array}{l}\text { From } \\
\text { TWRS Materials \& Corrosion }\end{array}$}} & \multicolumn{2}{|l|}{ Page 2 of 2} \\
\hline & & & & \multicolumn{2}{|c|}{ Date $9 / 18 / 96$} \\
\hline \multicolumn{4}{|l|}{ Project Title/Work Order } & \multicolumn{2}{|c|}{ EDT No. 615262} \\
\hline \multicolumn{6}{|c|}{$\begin{array}{l}1995 \text { Annual Cathodic Protection Survey Report for the Hanford } \\
200 \text { Area }\end{array}$} \\
\hline Name & MSIN & $\begin{array}{c}\text { Text } \\
\text { With All } \\
\text { Attach. }\end{array}$ & Text Only & $\begin{array}{l}\text { Attach./ } \\
\text { Appendix } \\
\text { Only }\end{array}$ & $\begin{array}{l}\text { EDT/ECN } \\
\text { Only }\end{array}$ \\
\hline
\end{tabular}

J. R. Divine

Chem Met, Ltd.

P. 0. Box 4068

West Richland, Washington 99352-0017

$x$

J. H. Haberman

Parsons Environmental Services, Inc.

1955 Jadwin Avenue, Suite 415

Richland, Washington 99352 